Mr. sc. Ivan Šprajc

\title{
INSTITUT IZUZEĆA SLUŽBENE OSOBE U ZAKONU O OPĆEM UPRAVNOM POSTUPKU
}

\author{
UDK: 347. 9 \\ Primljeno: 10.06. 2017. \\ Pregledni rad
}

Autor u radu obrađuje važan i zanimljiv, iako ponešto zanemaren institut izuzeća službene osobe. Tijekom analize instituta izuzeća ukazuje se na određenu normativnu zastarjelost ovog instituta kao i na dvojbena rješenja u odredbama posebnog upravnog zakonodavstva. U konačnici, pledira se za nastavak rada na usavršavanju ovog instituta te za nužna zakonodavna poboljšanja odgovarajućih odredbi Zakona o općem upravnom postupku.

Ključne riječi: izuzeće, službena osoba, upravni postupak, Zakon o općem upravnom postupku

\section{UVOD}

Institut izuzeća službene osobe neobično je važan upravnopostupovni institut. Njegova primjena omogućava nepristranost vođenja upravnog postupka kao i odlučivanja o upravnim stvarima. Objektivnost i nepristranost odlučivanja te zabrana konfudiranja osobnih motiva kao i motiva nevezanih za upravnu stvar koja je predmet postupka a koja se zabrana nalazi u osnovi instituta bitne su vrijednosti kojima se omogućuje realizacija drugih vrijednosti izraženih u osnovnim načelima općeg upravnog postupka. ${ }^{1}$ To su prije svih vrijednosti iz načela zakonitosti, načela utvrđivanja materijalne istine, načela samostalnosti i slobodne ocjene dokaza, ali jednako tako i načela učinkovitosti i ekonomičnosti te načela razmjernosti u zaštiti prava stranaka i javnog interesa - da nabrojim samo neka od načela. ${ }^{2}$

Sve do ulaska Republike Hrvatske u EU institut izuzeća nije bio često analiziran niti mu je posvećivana dužna pozornost. Ne vidim prihvatljiva razloga tome, osobito kada se uvidi kakvu važnost ovaj institut te prethodno spomenute vrijednosti na

1 V. u tom smislu i smjeru Babac, B., Upravno pravo (Odabrana poglavlja iz teorije $i$ praxisa), Osijek, 2004., koji točno zapaža da: "Stvarno i mjesno nadležno tijelo mora biti i nepristranim, što znači da njegovo odlučivanje ne smije biti utjecano osobnim elementima onoga koji u ime toga tijela postupa.", str. 851 .

2 Androjna, V., Upravni postopek in upravni spor, Ljubljana, 1992., str. 71. Ukazuje i na funkciju ostvarenja i zaštite načela objektivnosti koje da bi predstavljalo jedno od temeljnih načela upravnog postupka, jednako u interesu stranaka i tijela. Iako se radi o djelu vezanom za prethodnu verziju ZUP-a, mišljenja sam da se nikako ne može odreći vrijednost ovakvom stavu rečenog autora. 
Mr. sc. Ivan Šprajc: Institut izuzeća službene osobe u Zakonu o općem upravnom postupku Zbornik radova Pravnog fakulteta u Splitu, god. 55, 2/2018., str. 469.- 496.

kojima je zasnovan uživa unutar prava EU-a. Dovoljno je u tom pogledu spomenuti čl. 41. Povelje o temeljnim pravima EU-a u kojem je sadržan niz upravnopostupovnih prava pod zajedničkim nazivom prava na dobru upravu, ${ }^{3}$ te se podsjetiti da dotična Povelja ima konstitucionalni status. ${ }^{4}$ Njezina primjena - kolikogod dikcijom čl. 41. Povelje EU-a ograničena na postupovne situacije u kojima su involvirane institucije Unije - od značaja je i za nacionalna tijela država-članica kada provode pravo EU-a pa je izvan svake sumnje potrebno analizirati mjesto instituta izuzeća službene osobe i izvan normativnog konteksta određenog isključivo nacionalnim pravom RH. ${ }^{5}$ To osobito zato što je Europski sud pravde u svojim recentnijim odlukama pravo na dobru upravu označio kao „opće načelo prava Unije.“" Kao sastavni dio prava na dobru upravu institut izuzeća uklopljen je u zahtjev nepristranosti odlučivanja u javnoj upravi, a koji zahtjev, prema šire prihvaćenom mišljenju doktrine predstavlja postupovno subjektivno pravo koje je izravno korelirano sa zakonitošću akata na koje se ovo pravo primjenjuje. ${ }^{7}$ Međutim, funkcija nepristranosti javne uprave kao postupovnog elementa koji se mora osigurati u svakom postupku posjeduje i dodatnu normativnu funkciju. Dotična funkcija može se označiti kao objektivna i shvaća se kao normativni osigurač pravilne primjene prava u situaciji u kojoj javna uprava odlučuje primjenom diskrecijske ocjene. ${ }^{8}$ Kada se uoči takva, prizmatična narav nepristranosti, postaje jasnije kolika je važnost instituta izuzeća kao nosivog normativnog elementa vrijednosti i načela nepristranosti. ${ }^{9}$ Istodobno, nepristranost kao dio prava na dobru upravu od stupanja na snagu Povelje EU-a predstavlja sve češću pravnu osnovu u postupcima pred Europskim sudom pravde pa se i donedavni, u osnovi konstruktivni prigovori glede fragmentiranosti prakse u tom pogledu, čine

3 Povelja o temeljnim pravima EU-a (dalje: Povelja EU) kao važeći pravni akt svoju pravnu snagu stječe stupanjem na snagu Lisabonskog ugovora (Ugovor iz Lisabona kojim se mijenja Ugovor o Europskoj uniji i Ugovor o osnivanju Europske zajednice; OJ C 306) u prosincu 2009. Povelja EU-a sadrži čl. 41. koji, u relevantnom dijelu, glasi:

"1. Svatko ima pravo da institucije, tijela, uredi i agencije Unije njegove predmete obrađuju nepristrano, pravično i u razumnom roku."

4 V. u tom smislu Kristjánsdóttir, M. V., "Good administration as a fundamental right", u: Icelandic Review of Politics \& Administration, br. 1/2013, str. 239.

5 U tom smislu relevantni su čl. 51, st. 1. te čl. 52, st. 2. i 4. Povelje EU-a. Kristjándóttir, M. V, op. cit, str. 246-248 u tom smislu navodi prilično uvjerljive argumente kao ojačanje takvog stava; od zasnovanosti prava na dobru upravu na temeljnim načelima prava do razloga zbog kojih tzv. proceduralna autonomija država članica EU-a mora biti shvaćena kao ograničeno primjenjiva kategorija.

6 T. 49. Presude Europskog suda pravde u slučaju C-604/12 (H. N. v. Ministarstva pravde, jednakosti i reforme prava; ECLI:EU:C:2014:302) čime su tvrdnje M. V. Kristjándóttir dobile potvrdu (v. tekst prethodne bilješke).

V. u tom smislu i smjeru tumačenje čl. 41. Povelje EU-a Mendes J, Good Administration in EU Law and the European Code of Good Administrative Behaviour, European University Institute, Florence, Department of Law, EUI Working paper LAW, 2009/09, str. 4; dostupno na: http://cadmus.eui.eu/ bitstream/handle/1814/12101/LAW_2009_09.pdf;jsessionid=20A513526AB2A2FC7FBEDE9CFD80A9 $\mathrm{D} 2$ ? sequence $=3$ (pristupljeno 3. V. 2016.).

Mendes, J., op. cit, str. 5.

9 O mjestu i važnosti nepristranosti u kontekstu prava na dobru upravu v. Mendes, J., op. cit., str. 6-7. 
Mr. sc. Ivan Šprajc: Institut izuzeća službene osobe u Zakonu o općem upravnom postupku Zbornik radova Pravnog fakulteta u Splitu, god. 55, 2/2018., str. 469.- 496.

sve manje opravdanima. ${ }^{10}$ Presude ovog foruma u slučajevima poput C-604/12 (H. N. v. Ministarstva pravde, jednakosti i reforme prava; ECLI:EU:C:2014:302) ili C-439/11 P (Ziegler v. Europska komisija; ECLI:EU:C:2013:513), da spomenemo samo one recentnije, to rječito ilustriraju. Oba su slučaja problematizirala tzv. objektivnu nepristranost postupanja nadležnih institucija (u slučaju H. N. radilo se o upravnom tijelu države članice, u slučaju Ziegler o Europskoj komisiji) koji je pojam ovisan o postojećim normativnim jamstvima da će nadležno tijelo postupati na takav način koji može isključiti svaku legitimnu sumnju u njegovu nepristranost. S druge pak strane, subjektivna nepristranost posljedica je postupanja i ponašanja članova nadležnih tijela koji ne smiju postupati na način koji bi iskazao osobnu predrasudu odnosno drugu pristranost osobne naravi. ${ }^{11}$

Iako nije uključeno u Konvenciju za zaštitu ljudskih prava i temeljnih sloboda (dalje: Europska konvencija), pravo na dobru upravu te nepristrano postupanje nadležnih institucija nije ostalo izvan fokusa Vijeća Europe. Inicijalne aktivnosti ove europske institucije zabilježene su, doduše, u neobvezujućim dokumentima no postupanje i odlučivanje Europskog suda za ljudska prava, usmjereno na nepristranost suda i sudaca, ostavilo je traga i na postupanje upravnih tijela. ${ }^{12}$ Postupanje i odlučivanje Europskog suda za ljudska prava, iako usmjereno na nepristranost suda i sudaca, međutim, ostavilo je traga i na postupanje upravnih tijela ali i na postupanje institucija EU-a. ${ }^{13}$ Praksa Europskog suda za ljudska prava, unatoč relativnoj malobrojnosti slučajeva, ukazuje na nepostojanje bilo kakvih relevantnih dvojbi u pogledu važenja i značenja nepristranosti pa shodno tome i primjene instituta izuzeća u jamstvu prava na pravično suđenje kako je isto statuirano u Konvenciji za zaštitu ljudskih prava i temeljnih sloboda (Europska

10 Takve prigovore kao i uvodni pregled prakse Europskog suda pravde daje Cuculoska, I., "The Right to Good Administration to EU: Definition, Scope and Content", u: Iustinianus Primus Law Review, No 9, Vol. V, Summer 2014, str. 7-8; dostupno na: http://law-review.mk/pdf/09/Irena\%20Cuculoska.pdf (pristupljeno 28. IV. 2016.) kao i pregled starije prakse ovog Suda.

11 V. presudu u slučaju Ziegler v. Europska komisija, t. 155, te t. 52. presude u slučaju H. N. v. Ministarstvo pravde, jednakosti i reforme prava. Posebno je zanimljivo pitanje koje se u okviru slučaja $\mathrm{H}$. N. postavilo kao krucijalno; naime, može li objektivna nepristranost biti ugrožena normom nacionalnog prava koje propisuje redoslijed provođenja dvaju upravnih postupaka ukoliko se stranka svojim zahtjevom protivi takvom, unaprijed propisanom vođenju upravnih postupaka, a nadležno tijelo na redoslijedu inzistira (u konkretnom slučaju radilo se o postupku traženja azila kao primarnom odnosno postupku odobrenja supsidijarne zaštite kao sekundarnom postupku). Zaključak Suda negirao je takav zaključak te ustvrdio da iz perspektive prava na dobru upravu - kao načela EU-prava - ne postoji smetnja u tom pogledu.

12 Dobar pregled v. kod Váczi P, The institution of good administration in the Council of Europe, dostupno na: https://www.law.muni.cz/sborniky/cofola2008/files/pdf/sprava/vaczi_peter.pdf (pristupljeno 1. VI. 2016.) kao i Cuculoska I., op. cit, str. 17-19.

13 Dobru ilustraciju tvrdnje predstavlja i sljedeći citat stava Europske komisije navedenog u presudi u slučaju Ziegler v. EK. U t. 148. gore citirane presude Europskog suda pravde navodi: „U odnosu na temeljno pravo na pošteno suđenje i načelo dobre uprave, Komisija napominje da se ona ne može smatrati sudom u smislu članaka 47. Povelje i 6. EKLJP-a. Nadalje, Komisija priznaje da je očito vezana obvezom nepristranosti u okviru načela dobre uprave, osobito prilikom upravne istrage, ali smatra da je $u$ predmetnom slučaju poštovala takvu obvezu nepristranosti““. 
Mr. sc. Ivan Šprajc: Institut izuzeća službene osobe u Zakonu o općem upravnom postupku Zbornik radova Pravnog fakulteta u Splitu, god. 55, 2/2018., str. 469.- 496.

konvencija). ${ }^{14}$ Važnost instituta izuzeća te vrijednosti nepristranog odlučivanja, međutim, nadilazi i granice upravnopostupovnog prava. Njegova svrha, promotrena u nešto široj perspektivi, lako je uklopljivi element u naporu da se iskorijeni korupcija pa se normativni model formiran u institutu izuzeća može primijeniti i u takvom, pravno-političkom okviru iako u sklopu drugačijih instituta. ${ }^{15}$ Tu prije svega mislim na institut sukoba interesa koji dominira u recentno doba iako je njegova normativna srž zasada postupovnog prava. ${ }^{16}$ Zamjetno je da se instituti pod ovim nazivom, u osnovi kojih se nalaze postupovni modeli izgrađeni temeljem instituta izuzeća, danas mogu locirati u različitim zakonima. Većina tih zakona postupovno se ,naslanja“ na ZUP putem supsidijarne primjene potonjeg zakona što je činjenica vrijedna pažnje i memoriranja. ${ }^{17} \mathrm{~Pa}$ iako veze između izuzeća kao normativnog i sprečavanja sukoba interesa kao djelomično i normativno-političkog instituta nisu predmet ovog rada, vrijedi ih istaknuti kao dokaz u prilog tvrdnje o važnosti instituta izuzeća.

\section{USPOREDBA INSTITUTA IZUZEĆA SLUŽBENE OSOBE U ZUP-U IZ 1991. G. I U VAŽEĆEM ZUP-U}

S obzirom na to da važeći ZUP po svemu predstavlja kontinuitet regulacije upravnog postupka u odnosu na svoje prethodnike, smatram barem minimalno

14 Presude ovog foruma u slučaju Mežnarić v. Hrvatska (presuda od 15. VII. 2005.) odnosno u slučaju Kyprianou v. Cipar (presuda od 15. XII. 2005.) pružaju autoritavnu potvrdu ovakvog stava. Prijevod i kratki komentar prvonavedene presude v. Šprajc, I., „Mežnarić v. Hrvatska (Predmet br. 71615/01, Presuda Prvog vijeća Europskog suda za ljudska prava od 15. srpnja 2005.)“", u: Odvjetnik, br. 7-8/05, str. 48-50.

15 I kod definicije korupcije može se zamijetiti stanoviti broj definicija koje su vrlo bliske definicijama sukoba interesa odnosno situaciji koju institut izuzeća želi razriješiti. Tako primjerice Gunter definira korupciju kao "zlorabu javne vlasti za stjecanje privatne dobiti”. Gunter, F. R, "Corruption" (natuknica), u: Encyclopedia of social problems (V. N. Parrillo, editor), Sage, 2008., I. tom, str. 172-175.

16 V. uvodno o pojmu Bačić, A., Sukob interesa i pitanje odgovornosti u ustavnoj demokraciji, u: Rad Hrvatske akademije znanosti i umjetnosti: Razred za društvene znanosti, br. $512=49(2012)$, dostupno na: http://hrcak.srce.hr/index.php?show=clanak\&id_clanak jezik=123762 (pristupljeno 2. VI. 2016.), kao i Kušan, L., Sukob interesa, Zagreb-Split, 2003., T. Lankester, Conflict of Interest: A Historical and Comparative Perspective, dostupno na: http://www.oecd.org/site/adboecdanticorruptioninitiative/39368062.pdf (pristupljeno 10. VI. 2016.). U normativnom pogledu valja najprije analizirati odredbe Zakona o sprečavanju sukoba interesa u "Narodne novine" (dalje: NN) br. 26/11 do $57 / 15$, i to osobito odredbe poput čl. 1-2. te 6-20. Sličnosti naspram instituta izuzeća vide se već na pojmovnoj razini kada se pristupa definiranju sukoba interesa (prema Kušan, op. cit, str. 9, radi se o situaciji "u kojoj se sukobljavaju javni i privatni interes", odnosno situaciji "u kojoj dužnosnik ima privatni interes koji utječe ili može utjecati na njegovu nepristranost u obnašanju javne dužnosti”. Bačić, op. cit, str. 179, priklanja se takvom stavu i sintetizira različite perspektive na zajednički nazivnik definicije sukoba interesa kao situacije "kada se javni interesi ili vrijednosti kompromitiraju privatnim interesima".

17 Kao primjere zakonskih akata koji sadrže odredbe o sukobu interesa e.g. navodimo Zakon o državnim službenicima, Narodne novine br. 92/05 do 01/15, čl. 32-37, zatim Zakon o službenicima i namještenicima u lokalnoj i područnoj (regionalnoj) samoupravi, Narodne novine br. 86/08 i 61/11, čl. 38-41, a od recentnijih primjeraka iz zakonodavstva zanimljiv primjer nudi i Zakon o udrugama koji imperativno traži od udruge da u statut umetne i odredbe o načinu rješavanja sukoba interesa unutar udruge (čl. 13, st. 1, t. 15). 
potrebnim usporediti analizirani institut u sadašnjem te prethodnom ZUP-u. Pregled odredbi prethodno važećeg ZUP-a odmah ističe neke regulativne odlike instituta izuzeća u važećem ZUP-u. Prije svega, treba istaknuti da institut izuzeća u važećem ZUP-u sadrži manje pravnih odredbi pa je odmah uočljivo da postoje određene pravne praznine. To je posljedica okolnosti da u sadašnjem tekstu ZUP-a izuzeće službene osobe regulira isključivo čl. 24.

Usporedba pravnih normi koje reguliraju izuzeće u ZUP-u iz 1991. g. te u sadašnjem tekstu ZUP-a jasno ukazuju na postojanje nekih pravnih praznina $u$ sadašnjem zakonu. Tako je primjerice jasno da ne postoji niti jedna odredba koja bi bila normativni pandan odredbi čl. 48. ZUP-a iz 1991. koji je uredio pitanje izuzeća drugih službenih osoba (zapisničara). Štoviše, sadašnji tekst ZUP-a formulirao je razloge izuzeća isključivo u kontekstu odlučivanja o izuzeću službene osobe unutar javnopravnog tijela, izgubivši pri tom iz normativne perspektive mogućnost odlučivanja o izuzeću čelnika tijela. To je vidljivo iz izričaja koji se koristi na početku odredbi u st. 1-3, čl. 24. ZUP-a (,Čelnik tijela zaključkom će...“ odnosno „Čelnik tijela zaključkom može...“). Problem nastaje kada se postavi pitanje izuzeća čelnika tijela o čemu odlučuje nadležno tijelo iz st. 5. istog članka i to stoga što se gramatičkim tumačenjem odredbi st. 1-3. zaključuje o primjenjivosti ovih odredbi isključivo na pitanje izuzeća službene osobe, ali ne i na pitanje izuzeća čelnika tijela. Naravno, širokim tumačenjem ovog mjesta i uz malu pomoć analogije primjenjivost st. 1-3, čl. 24. ZUP-a bit će proširena i na iz teksta izostavljene situacije odlučivanja o izuzeću čelnika tijela. Takav interpretativni postupak, ipak, ne može negirati nomotehničku slabost analiziranih mjesta pa o tome buduća novela ZUP-a mora voditi računa. Jednako tako mora se voditi računa da st. 5, čl. 24. ZUP-a ne uzima u obzir mogućnost traženja izuzeća čelnika drugostupanjskog tijela što također može predstavljati problem u nekom upravnom postupku. Nadalje, a u istom kontekstu podnormiranosti, vidljivo je da u važećem ZUP-u nedostaju odredbe koje bi uredile pitanje dopustivosti postupanja službene osobe nakon što je iniciran postupak izuzeća. Ovaj nedostatak smatram ozbiljnim uzme li se u obzir nemogućnost da se, kao u prethodnom uočenom nedostatku, odgovarajućom interpretacijom premosti naznačena pravna praznina. Međutim, jednako tako moguće je uočiti da sadašnji ZUP sadrži neke norme koje ZUP iz 1991. g. nije sadržavao u normiranju analiziranog instituta. Fakultativni razlozi izuzeća službene osobe u važećem ZUP-u pomno su legalno definirani u st. 3, čl. 24. ZUP-a. Nadalje, dužnost prijave postojanja bilo kojeg - obligatornog ili fakultativnog - razloga izuzeća sada je proširena na svaku osobu koja sudjeluje u postupku. ${ }^{18}$ Osim razlika, postoje i sličnosti između uspoređenih zakonskih tekstova u kontekstu izuzeća, a od potonjih je po mom mišljenju najznačajnija gotovo potpuni identitet razloga obligatornog izuzeća. ${ }^{19}$ Međutim, ova okolnost nije nužno preporučljiva odnosno pozitivna. No, o tome više na drugom mjestu ovog rada. ${ }^{20}$ Zaključno možemo ustvrditi da je institut izuzeća

18 Usp. čl. 24, st. 4. važećeg ZUP-a i čl. 43. ZUP-a iz 1991. g.

19 Jedina, i po svom značenju ipak minorna razlika, krije se u nepostojanju pojma "hranitelja" u postojećim odredbama ZUP-a o obligatornom izuzeću.

20 V. t. 3.1.3. ovog rada. 
Mr. sc. Ivan Šprajc: Institut izuzeća službene osobe u Zakonu o općem upravnom postupku Zbornik radova Pravnog fakulteta u Splitu, god. 55, 2/2018., str. 469.- 496.

u važećem ZUP-u modificiran u odnosu na referentne odredbe ZUP-a iz 1991. g. Modifikacije idu u različitim smjerovima pa je moguće uočiti i odredbe koje sadašnji ZUP izostavlja (a njegov normativni prethodnik ih sadrži), ali je jednako tako moguće detektirati odredbe koje važeći ZUP u odnosu na ZUP iz 1991. g. čine nedostatnim. Naposljetku, u važećem ZUP-u postoje odredbe koje institut izuzeća usavršavaju i poboljšavaju u odnosu na istovrsne odredbe ZUP-a iz 1991. g.

\section{INSTITUT IZUZEĆA SLUŽBENE OSOBE IZ ČL. 24. ZUP-A}

Institut izuzeća i u pozitivnopravnoj varijanti sadrži dvije vrste razloga za izuzeća pa shodno tome možemo razlikovati i dvije podvrste izuzeća; a) obligatorno te b) fakultativno izuzeće.

\subsection{Obligatorno izuzeće}

Dotična podvrsta izuzeća temelji se na imperativnoj dužnosti čelnika tijela da izuzme službenu osobu od vođenja postupka odnosno od rješavanja upravne stvari ako se na strani dotične službene osobe stekne makar i jedan od razloga za obligatorno izuzeće iz čl. 24, st. 1-2. ZUP-a. Dakle, obligatorno izuzeće kao podvrsta izuzeća temelji se na dvije bitne pravne karakteristike; prvoj, postojanju makar i jednog razloga za obligatorno izuzeće; te drugoj, strogoj (kogentnoj) postupovnoj normi koja imperativno traži od nadležnog tijela da donese rješenje o izuzeću kada se ustanovi postojanje makar i jednog razloga za obligatorno izuzeće. ${ }^{21}$ Drugačije rečeno, okolnosti koje su navedene kao razlozi obligatornog isključenja valja ustanoviti pa onda bez ispitivanja mogućeg utjecaja na objektivnost i nepristranost službene osobe postupovno i bez mogućnosti primjene diskrecije označiti zaprekom daljeg sudjelovanja službene osobe u konkretnom postupku. ${ }^{22}$ Prema čl. 24, st. 1. ZUP-a, nadležno tijelo jest čelnik onog tijela koje vodi upravni postupak, a kogentnost norme te razloga obligatornog izuzeća pruža osnovu za zaključak da službena osoba opterećena postojanjem razloga za izuzeće ne smije poduzeti niti jednu službenu radnju nakon utvrđivanja ove prekluzivne okolnosti. Okolnost, međutim, da zabrana takvog sadržaja nije našla svoje mjesto u čl. 24. ZUP-a predstavlja problem jer rokovi u kojima se upravna stvar mora riješiti teku i nadalje bez obzira na to što se tijekom upravnog postupka pojavi potreba za odlučivanjem o izuzeću kao i što se eventualno postojanje razloga za izuzećem mora postupovno pravilno i valjano ispitati. U tom smislu, posebnu dimenziju ovog problema mogu predstavljati one

${ }^{21}$ Babac, B., op. cit, str. 858. govori o obligatornom izuzeću kao ,isključenju“. što je podvrsta instituta ,rasjedanja“.

22 U tom smislu, tvrdnju B. Babca, op. cit, da se kod razloga obligatornog izuzeća u postupovnom smislu radi o neoborivim presumpcijama, valja razmotriti s rezervom. Naime, razloge obligatornog izuzeća valja dokazati, a ne radi se, kao kod spomenute vrste presumpcija, o nedopustivosti protudokaza dotičnih okolnosti. V. razmatranja koja potvrđuju naš stav Vrban, V., Država i pravo, Zagreb, 2003., str. 441-443. 
radnje čije se poduzimanje ne smije odgađati odnosno one koje svojim posljedicama mogu presudno i nepovratno utjecati na način odlučivanja u upravnoj stvari. Povrh toga, valja uzeti u obzir da je ovlaštenje službene osobe da postupa u upravnoj stvari općenite naravi po njegovom opsegu pa sve dok se ne odluči o izuzeću ne postoji pravna osnova temeljem koje bi se službenoj osobi zabranilo dalje poduzimanje službenih radnji u postupku. Zbog takvih situacija smatram da je potrebno čl. 24. ZUP-a dopuniti uvrštenjem posebne odredbe nalik na onoj iz čl. 43. ZUP-a iz 1991. kao i da treba razmotriti mogućnost da se u ZUP uvrsti odredba snagom koje bi rok za odlučivanje u upravnoj stvari bio produžen za vrijeme ispitivanja i odlučivanja o postojanju razloga za izuzećem službene osobe. ${ }^{23}$ Tako bi se, s jedne strane, čelniku tijela omogućilo da bez vremenskog pritiska ispita navode o postojanju okolnosti zbog kojih se ima izuzeti službena osoba, a s druge bi se strane stranke odvratile od korištenja ovog instituta kao taktičkog poteza kojim se otežava postupanje tijelu koje vodi postupak. Naposljetku i najvažnije od svega, prevenirale bi se prethodno spomenute situacije u postupku zbog kojih bi u pitanje mogao doći ishod upravnog postupka kao i pravilnost prethodnog postupanja u postupku.

I dok je kod postojanja razloga obligatornog izuzeća iz st. 1, čl. 24. ZUP-a dužnost čelnika tijela jasna, problemi nastaju kada se uoči formulacija razloga iz st. 2. istog članka. Sam razlog izuzeća, međutim, nije osobito sporan. Naime, involviranost službene osobe u prvostupanjskom postupku predstavlja diskvalifikatornu okolnost za njegovo službeno djelovanje u drugostupanjskom postupku. Motivaciju ovakve zakonodavne odredbe nije teško pronaći; devolutivnost žalbe bila bi u potpunosti kompromitirana ako bi se prihvatio stav da je ista službena osoba koja je odlučivala u prvom stupnju ovlaštena odlučivati o toj žalbi u drugom stupnju. ${ }^{24}$ Dakle, osim razloga nepristranosti i objektivnosti, ovdje valja pridodati i razloge zaštite ustavnog prava na žalbu kao bitnog razloga koji opravdava izuzeće službene osobe.

Međutim, problematičnom se čini formulacija st. 2, čl. 24, kada se uoči da ova odredba govori isključivo o „vođenju drugostupanjskog postupka“ a da istodobno ne spominje „rješavanje upravne stvari“. Naime, razlika je to koju zakonodavac u ZUP-u jasno uočava i primjenjuje u uvodnom dijelu odredbe st. 1, ali i u st. 3, odnosno u st. 6. čl. 24. pa je tim izraženiji nedostatak st. 2. istog članka. Upravo zbog navođenja obje ključne sintagme u više odredbi čl. 24. ali ne i u odredbi st. 2., postavlja se pitanje dopustivosti ekstenzivnog tumačenja ove odredbe. Ekstenzivnost bi se sastojala u proširivanju suprotno izričitoj formulaciji iz st. 2. značenja postojeće sintagme koja se odnosi isključivo na vođenje drugostupanjskog postupka na način da ona obuhvati i zabranu odlučivanja u drugostupanjskom postupku. Nije sporno

23 Čl. 43. ZUP-a iz 1991. g. glasio je: "Službena osoba koja bi imala da rješava u određenoj upravnoj stvari ili da obavi koju radnju u postupku, čim sazna da postoji koji od razloga za izuzeće iz članka 42. ovog zakona, dužna je prekinuti svaki daljnji rad na predmetu i o tome obavijestiti organ nadležan za rješavanje o izuzeću. Ako službena osoba smatra da postoje druge okolnosti koje opravdavaju njezino izuzeće, obavijestit će o tome isti organ, ne prekidajući rad."

24 Rečeno vrijedi i za prigovor ako je isti oblikovan kao devolutivno pravozaštitno sredstvo; v. čl. 157. ZUP-a. Androjna, V., op. cit, str. 72., opravdano upozorava da se izuzeće službene osobe koja je sudjelovala u postupku prvog stupnja odnosi kako na službenu osobu koja je samostalno djelovala unutar prvostupanjskog postupka tako i na osobu koja je bila članom kolegija. 
da je doktrinarno praktički neobranjiv stav o prihvatljivosti rješavanja upravne stvari od strane iste službene osobe u prvom kao i u drugom stupnju upravnog postupka no problem predstavlja nedostatan te pravno nedosljedan tekst st. 2 , čl. 24. ZUP-a. Stoga kao jedini održiv izlaz iz zatečene normativne situacije - do novele ovog mjesta u ZUP-u - vidimo takvo tumačenje koje polazi od različitosti, ali i nedvojbene uzročno-posljedične povezanosti vođenja upravnog postupka i odlučivanja. Radi se o dvije grupe postupovnih radnji kod kojih poduzimanje jedne grupe radnji (vođenje postupka do odlučivanja) u bitnome utječe na sadržaj druge grupe radnji (odlučivanje) zbog jasnih logičkih i sadržajnih veza. Ako je tome tako, a smatram da to nije sporno, tada je jasno da je zbog superiornosti odlučivanja o upravnoj stvari (naspram postupanja u jednoj ili više postupovnih radnji) neprihvatljivo zbog jednog te istog razloga (involviranost u prvostupanjski postupak) istodobno zabraniti vođenje drugostupanjskog postupka a dopustiti odlučivanje u istom. Naravno, buduća novela ZUP-a morala bi korigirati netom naznačeni nedostatak normativnog teksta.

\subsubsection{Pojedini razlozi obligatornog izuzeća}

\subsubsection{Status stranke, suovlaštenika, suobveznika, svjedoka, vještaka ili osobe ovlaštene za zastupanje (t. 1, st. 1, čl. 24. ZUP-a)}

Neprihvatljivost istodobne egzistencije navedenih statusa i statusa službene osobe proizlazi iz načelne neprihvatljivosti korištenja službenih ovlasti u svojoj stvari (nemo ius sibi dicere potest). To vrijedi i za statuse suovlaštenika odnosno suobveznika stranke jer su oni načelno izjednačeni sa strankom. ${ }^{25}$ Pravna povezanost te dužnosti i ovlasti koje osoba ovlaštena za zastupanje stranke ima u tom statusu kao i njezin odnos sa strankom sprečavaju istodobno nepristrano i objektivno odlučivanje te postupanje u upravnom postupku. ${ }^{26}$ Naposljetku, statusi svjedoka i vještaka nespojivi su sa statusom službene osobe ali ne iz razloga koji se uobičajeno navode $u$ našoj doktrini (ili ne samo iz istih razloga). ${ }^{27}$ Po našem mišljenju subjektivnost nije jedini razlog ove odredbe nego je ona barem u jednakoj mjeri motivirana i spoznajom da se odlučivanje u upravnom postupku mora fokusirati na zaštitu javnih interesa, a to bi bilo nemoguće ako se službena osoba mora iscrpljivati u drugim statusima tijekom postupka. Dakle, upravo u dužnosti službene osobe da kao predstavnik javnopravnih tijela promiče javni interes vidimo posebno opravdanje izuzeća kao instrumenta kojim zakonodavac nastoji isključiti

25 Tako i Turčić, Z., Komentar Zakona o općem upravnom postupku, treće, dopunjeno izdanje, Zagreb, 2012., str. 70 .

26 V. ilustraciju rečenog na primjeru odvjetništva te odnosa između odvjetnika i stranke u čl. 63, st. 3. ZUP-a te u čl. 13. (odvjetnička tajna) Zakona o odvjetništvu, Narodne novine 9/94 do 18/11.

27 V. u tom smislu Turčić, Z., ibid, koji navodi isključivo razlog subjektivnosti povezane s navedenim ulogama kao prepreku istodobnog obnašanja dužnosti službene osobe. 
utjecaj privatnog interesa na javni interes. ${ }^{28}$ Drugačije rečeno, smatram da se radi o zabrani kumulacije funkcija u postupku barem u istoj mjeri kao i o zabrani izlaganja službene osobe djelovanju subjektivnih motiva koji su, uzgred, praktički neodvojivi od funkcije svjedoka te praktički zanemarivi kod pravilno provedenog vještačenja. Nadalje, upravo je dotična opterećenost zaštitom javnog interesa po svom utjecaju toliko dalekosežna da bi imalo postupovnog smisla priječiti službenoj osobi, i u nekom periodu nakon prestanka službene dužnosti, sudjelovanje u odgovarajućim upravnim postupcima kao što je, primjerice, zastupnik stranke. Dužnost čuvanja službenih tajni i povjerljivih podataka, problematično korištenje osjetljivih službenih informacija, sve su to razlozi zbog kojih je austrijski zakonodavac pri noveli svog parnjaka ZUP-u upisao ove okolnosti kao razlog sprečavanja bivših službenih osoba od sudjelovanja u upravnom postupku. ${ }^{29} \mathrm{I}$ u tom smjeru preporučljivo bi bilo razmotriti rečeno kao mogući predmet buduće novele ZUP-a.

\subsubsection{Obiteljska povezanost sa strankom ili osobom ovlaštenom za zastupanje (t. 2, st. 1, čl. 24. ZUP-a)}

Ratio ove odredbe a zapravo prepreke sudjelovanju službene osobe u postupku jest praktički notoran. Bliske obiteljske veze sa strankom (osobom ovlaštenom za zastupanje stranke) nije potrebno posebno elaborirati u tom kontekstu. ${ }^{30}$ Analizi je, međutim, dostupan opseg rečene odredbe. U tom kontekstu potrebno je ukazati na problem neuvažavanja promjena koje su se dogodile u regulaciji obiteljskih odnosa u nas. Nažalost, neuvažanje u pitanju nije potpuno već ostavlja dojam arbitrarnosti te selektivnosti. Teza o selektivnosti zasnovana je na dvije zakonodavne radnje koje se pokazuju nepovezanima i teško obranjivima. Naime, iz normativnog teksta ZUP-a iz 1991. g. koji je, očito, poslužio kao osnova za regulaciju instituta izuzeća u sadašnjem ZUP-u, s pravom je izostavljen pojam ,hranitelja“. Riječ je o pravno opsoletnom institutu za koji više ne postoji normativno opravdanje njegova uključenja u tekst ZUP-a. Međutim, tvorci ZUP-a nisu nastavili s normativnim ažuriranjem teksta ZUP-a na način da u njega uključe i one institute koji su $\mathrm{u}$ međuvremenu našli svoj put u relevantne propise a prije svih tu mislilo se na propise obiteljskog prava. Naravno, neke od promjena u korpusu obiteljskopravnih zakona dogodile su se nakon stupanja na snagu ZUP-a, no ipak smatram da se i u doba stvaranja ZUP-a moralo učiniti više na izjednačavanju izvanbračnih drugova s bračnim drugovima u segmentu razloga za izuzeće, a neke od odredbi tada važećeg zakonodavstva koje su regulirale istospolne zajednice također su se mogle tumačiti

28 Tako i Pünder, H., "Verwaltungsverfahren", u: Erichsen H.V.; Ehlers D, (Hrsg.), Allgemeines Verwaltungsrecht, 14. izdanje, 2010., str. 450.

29 V. opširnije Wielinger, G., Einführung in das österreichische Verwaltungsverfahrenrcht und das Recht der österreichischen Verwaltnugsgerichtsbarkeit, Graz, 2014., str. 31.

30 Dostatno je, mislim, u ovom kontekstu podsjetiti se povoda postojanja instituta izuzeća kako ga navodi Androjna, op. cit, str. 71. i ukazuje na potrebu da se iz postupka izuzmu službene osobe koje su u određenom odnosu prema stranci ili upravnoj stvari. 
Mr. sc. Ivan Šprajc: Institut izuzeća službene osobe u Zakonu o općem upravnom postupku Zbornik radova Pravnog fakulteta u Splitu, god. 55, 2/2018., str. 469.- 496.

in favorem njihova uvrštavanja u čl. 24. ZUP-a. ${ }^{31}$ Dalji razvoj obiteljskopravnog zakonodavstva potvrdio je moje teze pa, nakon više od pet godina od stupanja na snagu ZUP-a, postoje argumenti za tvrdnju da su odredbe ZUP-a o izuzeću postale opsoletne te time potencijalno i preprekom za ostvarivanje pune jednakosti svih oblika zajedničkog života u upravnopostupovnom smislu. Naravno, to nisu učinci ZUP-a na koje se može pristati pa stoga sljedeći ekskurs ima za svrhu upozoriti na potrebu noveliranja ZUP-a u rečenom segmentu.

Naime, sadašnji Obiteljski zakon ekstenzivno je izjednačio učinke izvanbračne s bračnom zajednicom. ${ }^{32} \mathrm{U}$ spomenutom propisu izjednačenje instituta izvanbračne i bračne zajednice u pogledu imovinskih, osobnih pa i mnogih drugih učinaka steklo je status osnovnog načela (čl. 11. OZ-a). Takav normativni status izvanbračne zajednice dodatno je potvrđen nedvosmislenom odredbom st. 3, čl. 11. OZ-a prema kojoj nepovoljno postupanje prema izvanbračnim drugovima bez objektivnog opravdanja predstavlja diskriminaciju temeljem obiteljskog statusa. ${ }^{33} \mathrm{U}$ prilog teze može se navesti i pravna činjenica priznavanja izvanbračne zajednice i od strane ustavotvorca pa da se zaključi kako je zakonodavac pri svakom reguliranju, a osobito ovako bitnih akata kao što je ZUP, tu okolnost morao valjano evaluirati. ${ }^{34}$ Kada se tome doda i nemogućnost da se ustanovi postojanje bilo kojeg makar i minimalno prihvatljivog razloga ovakvog zakonodavnog ignoriranja izvanbračne zajednice, tada je jasno da se već prilikom njegova koncipiranja veća pozornost morala posvetiti ovom segmentu obiteljskopravnih odnosa te da se može zaključiti o normativnom propustu u sadašnjem sadržaju čl. 24, st. 1, t. 2. ZUP-a. ${ }^{35}$

Međutim, osim OZ-a, od važnosti je i Zakon o životnom partnerstvu osoba istog spola. ${ }^{36}$ Naime i u citiranom zakonskom aktu postoje nedvosmislene odredbe koje se tiču učinaka kako životnog partnerstva tako i neformalnog životnog partnerstva a koje su nedvosmislene u izjednačavanju životnih partnera s bračnim drugovima

31 Na ovom mjestu ponajprije referiramo na tada važeće odredbe Obiteljskog zakona (iz 2003. g.) odnosno Zakona o istospolnim zajednicama (također iz 2003. g.). Tako je primjerice kada je u pitanju drugospomenuti zakonski akt jasno naglašena zabrana diskriminacije istospolnog partnera (čl. 21.) koja je pružala dovoljan poticaj za uvrštenje i istospolnog partnera u čl. 24. ZUP-a.

32 Obiteljski zakon, Narodne novine 103/15; dalje: OZ.

33 Od važnosti je, pored spomenute odredbe i st. 2. Obje navedene odredbe, čl. 11, st. 2-3. glase: “(2) Izvanbračna zajednica koja ispunjava pretpostavke iz stavka 1. ovoga članka stvara osobne i imovinske učinke kao bračna zajednica te se na nju na odgovarajući način primjenjuju odredbe ovoga Zakona o osobnim i imovinskim odnosima bračnih drugova, odnosno odredbe drugih zakona kojima se uređuju odnosi u poreznim stvarima, osobni, imovinski i drugi odnosi bračnih drugova. (3) Nepovoljno postupanje prema izvanbračnim drugovima u pogledu pristupa koristima, povlasticama, ali i obvezama zajamčenim bračnim drugovima koje ne može biti opravdano objektivnim razlozima te koje nije nužno za ostvarenje istih predstavlja diskriminaciju temeljem obiteljskog statusa."

34 V. čl. 61, st. 3. Ustava RH Narodne Novine br. 56/90 do 05/14. Tekst Ustava RH citiran prema redakcijskom pročišćenom tekstu objavljenom na web-stranicama Ustavnog suda RH (http://www.usud. $\mathrm{hr} /$ sites/default/files/dokumenti/Redakcijski_prociscen_tekst_Ustava_Republike_Hrvatske_Ustavni sud_Republike_Hrvatske_15._sijecnja_2014_.pdf) kojem je pristupljeno 1. VI. $201 \overline{6}$.

35 U austrijskom pandanu ZUP-a prema sadržaju par. 36a, st. 1, al. 5. u vezi s par. 7, st. 1. postojanje izvanbračne veze između službene osobe i sudionika upravnog postupka indikacija je za izuzeće službene osobe. U potvrdu v. Wielinger, G., op. cit, str. 32.

36 Spomenuti zakon objavljen je u Narodnim novinama br. 92/14, dalje: ZŽP. 
i to baš u segmentu postupovnog prava, ${ }^{37}$ ili se lege artis mogu tumačiti u cilju izjednačavanja rečenih učinaka s onima izvanbračne zajednice. ${ }^{38}$ Već je ovakav uvid - iako nužno nepotpun - dostatan da učvrsti naš zaključak o potrebi dopune ZUP-a. Ovo vrijedi tim više jer odredba čl. 24. spada među temeljne odredbe ZUP-a čija neizmjenjivost putem posebnih zakona nije dopuštena te nas uvodi u cijeli niz interpretativnih problema. ${ }^{39}$ Stoga smo mišljenja da je novela ZUP-a u opisanom segmentu ne samo potrebna nego i nužna. ${ }^{40}$ Do njezina koncipiranja i uzakonjenja potrebno je preporučiti svim službenim tijelima i osobama da interpretacijom uzmu u obzir spomenute zakonodavne promjene te činjenice iz OZ-a i ZŽP-a kako ne bi drugačijim postupanjem uzrokovali diskriminaciju u primjeni ZUP-a. Do diskriminacije bi svakako došlo jer ako se usporede postupovne posljedice koje brak ima u području primjene čl. 24. ZUP-a naspram posljedica koje ima odnos između izvanbračnih drugova - kao i odnos između osoba istog spola koji se nalaze u odnosu životnog partnerstva - jasno se uočava diskriminacija bračnih drugova. ${ }^{41}$

\subsubsection{Posebni oblici povezanosti sa strankom ili osobom ovlaštenom za zastupanje (t. 3, st. 1, čl. 24. ZUP-a)}

U navedenoj odredbi kao razlog obligatornog izuzeća navode se odnosi skrbništva odnosno posvojenja. Posebnost navedenih odnosa posljedica je njihove specifične obiteljsko-pravne naravi kao i pravnih posljedica koje dotični instituti izazivaju. ${ }^{42}$

Kako se primjenom ovih instituta zasnivaju ili „trajni odnos roditelja i djeteta“ (posvojenje) ili se „nadomješta roditeljska skrb“ (za skrbništvo nad djetetom) odnosno se „osigurava zaštita onih prava i interesa koji su mu odlukom suda o lišenju poslovne sposobnosti ograničeni“ (za punoljetne štićenike) stvaraju se pretpostavke za aktivaciju instituta izuzeća. Pravno je nemoguće obraniti stav da se unatoč ovakvim oblicima povezanosti može očuvati nepristranost odnosno objektivnost u postupku ako bi službena osoba bila dio takvog odnosa povezanosti. 43

37 Na ovom mjestu kao nedvosmislenu i zakonski ojačanu ilustraciju valja ukazati na sadržaj čl. 37, st. 4. ZŽP-a: "Životni partneri imaju jednaka postupovna prava i status u svim sudskim i upravnim postupcima kao i bračni drugovi."

38 Tu prije svih referiramo na odredbe čl. 6. te čl. 4. (učinci neformalnog životnog partnerstva osobito st. 2. koji izravno govori o "javnopravnom položaju”) temeljem kojih se neformalno životno partnerstvo izjednačuje po učincima s izvanbračnom zajednicom.

39 V. više o naznačenoj problematici Šprajc, I., "Uvjeti propisivanja posebnog upravnog postupka: usporedba novog i starog ZUP-a”, u: Hrvatska pravna revija, br. 1/2011, str. 58-66.

40 U austrijskom pandanu ZUP-a prema sadržaju par. 36a, st. 1, al. 6. u vezi s par. 7, st. 1. postojanje veze utemeljene na registriranom partnerstvu između službene osobe i sudionika upravnog postupka indikacija je za izuzeće službene osobe. U potvrdu v. Wielingera, op. cit, str. 32.

41 U potvrdu ovakvog stava v. i Pündera, op. cit, str. 452.

42 Usp. u tom smjeru i smislu čl. 180, st. 1. OZ-a za posvojenje, odnosno čl. 218. OZ-a za skrbništvo.

43 Analizu obligatornog razloga za izuzeće iz st. 2, čl. 24. v. u tekstu ovog rada između bilješki br. 29-31. 
Mr. sc. Ivan Šprajc: Institut izuzeća službene osobe u Zakonu o općem upravnom postupku Zbornik radova Pravnog fakulteta u Splitu, god. 55, 2/2018., str. 469.- 496.

\subsection{Fakultativno izuzeće}

Fakultativno izuzeće kao podvrsta instituta izuzeća zasnovana je na postojanju najmanje dva bitna normativna elementa; prvo, postojanje nekog od razloga koji dovode u sumnju nepristranost službene osobe; te drugo, disjunktivnoj normi koja pruža nadležnom tijelu mogućnost - ali ne postavlja obvezu - izuzeća službene osobe na koju se prvonavedeni razlog odnosi. Drugačije rečeno, izuzeće koje se opravdava nekim od razloga navedenih u čl. 24, st. 3. ZUP-a utemeljeno je na primjeni slobodne (diskrecijske) ocjene rezultat koje je odluka nadležnog tijela o postojanju uzroka pristranosti službene osobe u konkretnom upravnom postupku.

Potrebno je napomenuti i to da su razlozi navedeni u prve tri točke st. 3, čl. 24. ZUP-a navedeni samo kao primjer. Da je tome tako zaključiti se može iz formulacije t. 4. istog normativnog mjesta koja je generalne naravi te omogućuje podvođenje i drugih razloga moguće pristranosti službene osobe. Egzemplifikativna metoda koju je u toj odredbi koristio zakonodavac pokazuje se ispravnim načinom uređenja ovog dijela instituta izuzeća. Razlog tome leži u nemogućnosti precizne detekcije svih mogućih uzroka sumnje u nepristranost službene osobe zbog kojih je potrebno razmotriti izuzimanje službene osobe iz konkretnog upravnog postupka. Stoga se pokazuje pragmatičnim i potpuno prihvatljivim odrediti presumptivno najčešće razloge aktiviranja ove podvrste izuzeća, ali bez isključenja drugih mogućih razloga. Pri ocjeni konkretne situacije i odlučivanju o eventualnom postojanju razloga za fakultativno izuzeće nadležno tijelo dužno je osobito voditi računa o javnim interesima i o privatnim interesima stranaka. Djelomično se obje spomenute vrste interesa poklapaju; to je slučaj s očuvanjem nepristranosti i objektivnosti. Vrijednosti su to za čije je održanje osobito zainteresirano odnosno javnopravno tijelo ali i stranka. ${ }^{44}$ Naime, postupanje i odlučivanje koje je kontaminirano makar i natruhama pristranosti bit će podložno prigovorima i nadzornim postupcima po pravnim lijekovima koji poznaju kao poseban razlog i razlog pristranosti službene osobe. ${ }^{45}$ Učinkovitije i ekonomičnije odlučivanje javnopravnih tijela trebalo bi biti sastavnim elementom javnog interesa što će biti lakše ostvariti ako se povodom odlučivanja ne stvaraju sumnje u osobnu zainteresiranost službene osobe. Na taj se način načelo učinkovitosti i ekonomičnosti ostvaruje u upravnom postupku. Stoga je u najboljem interesu samog javnopravnog tijela o kojem se radi pa i u javnom interesu da se eliminiraju čak i najmanji tragovi pristranosti u odlučivanju o upravnoj stvari.

Niti materijalno pravo stranke ostvarenju kojeg služi vođenje upravnog postupka ne smije se zanemariti kao razlog održanja nepristranosti i objektivnosti službene

44 V. bilješku br. 2. ovog rada.

45 Budući da je žalba opći pravni lijek u upravnom postupku može se koristiti i zbog razloga pristranosti službene osobe što ukazuje na okolnost da se i bez traženja izuzeća tijekom prvostupanjskog postupka razlog pristranosti može isticati u žalbi. U kategoriju iskoristivih pravnih lijekova svakako spada i prijedlog za obnovu postupka. O tome v. pod t. 3.3.3. ovog rada. U potvrdu ovog stava v. i nešto stariju upravnosudsku praksu koja je, smatram, i nadalje prihvatljiva. Prema sentenci Upravnog suda RH: „O zahtjevu za izuzeće stavljenom u žalbenom postupku više se ne može samostalno rješavati, već samo kao o jednom od žalbenih razloga.“(USH, br. Us-307/85 od 22. V. 1985.). 
osobe koja u tom postupku odlučuje. Tome valja dodati da je cilj svakog normativno uređenog postupka donošenje pravične odluke, a do nje se može stići tek poštovanjem stanovitih minimalnih zahtjeva glede odlučivanja u postupku. ${ }^{46}$ Sastavni dio takvih zahtjeva jesu vrijednosti nepristranosti te objektivnosti za ostvarenje kojih odgovara službena osoba. Stoga je posve opravdano izuzeti službenu osobu kod koje se objektivna nepristranost dovodi u sumnju na bilo koji način koji stvara dojam pristranosti. Povjerenje u osobnu nezainteresiranost službene osobe uže, stranačke javnosti, ali i šire javnosti bitan je dio nepristranosti i povjerenja koje svi sudionici u postupku moraju imati kako bi prihvatili rezultate upravnog postupka. ${ }^{47}$ Iz perspektive stranaka odluka o (ne)postojanju razloga za fakultativno izuzeće pokazuje se kao izrazito značajna. Naime, kroz tu odluku stranke stječu dojam o uvažavanju njihovih pravnih interesa od strane nadležnog upravnog tijela. Stoga je ova odluka izuzetna prigoda da se pokažu sve odlike dobre uprave, a istodobno strankama omogući korištenje svih prava koje pravo na dobru upravu pretpostavlja.

\subsubsection{Pojedini razlozi fakultativnog izuzeća}

Rečeno nas upućuje na analizu pojedinih razloga za fakultativno izuzeće. Pri tome je osobito značajno ne ispustiti iz vida okolnost da pored navedenih razloga mogu postojati i drugi razlozi koji kompromitiraju sposobnost službene osobe da djeluje u upravnom postupku.

\subsubsection{Bliski osobni odnos službene osobe $i$ stranke odnosno zastupnika stranke (t. 1, st. 3, čl. 24. ZUP-a)}

Dotični razlog ostvaruje se izvan osobnih odnosa koji su navedeni kao razlozi za obligatorno izuzeće (t. 1-3, st. 1, čl. 24.ZUP-a). Dakle, neće se raditi npr. o rodbinskom odnosu ali se može raditi o primjerice notornom prijateljskom ili neprijateljskom odnosu, kumskim vezama i sl. ${ }^{48} \mathrm{U}$ krug bliskih osobnih odnosa svakako po mom mišljenju ulaze i sporni odnosi koji se razrješuju ili su se razrješavali u sudskom ili drugom pravnom sporu pri čemu je upitan vremenski element takvog odnosa. Ovlast nadležnog tijela da procijeni prirodu kao i postojanje bliskog osobnog odnosa mora procijeniti i dotične dileme te biti valjano obrazložena. Kriterij procjene je nepristranost i neovisnost službene osobe naspram stranke (zastupnika stranke) i sposobnost službene osobe da bez pritisaka koji potječu iz njezine privatnosti odlučuje u postupku.

46 Tako i Röhl, K. F.; Röhl, H. C., Allgemeine Rechtslehre-ein Lehrbuch, 3. izdanje, Köln-München, 2008., str. 508-511 uz dalju elaboraciju svrha postupovnog prava.

47 V. pregled takvih teorija i istraživanja kod Röhl, K. F.; Röhl, H. C., op. cit, str. 513-516.

48 Tako i Turčić, op. cit., str. 72. 
Mr. sc. Ivan Šprajc: Institut izuzeća službene osobe u Zakonu o općem upravnom postupku Zbornik radova Pravnog fakulteta u Splitu, god. 55, 2/2018., str. 469.- 496.

\subsubsection{Poslovni (gospodarski) odnos službene osobe $i$ stranke (t. 2, st. 3, čl. 24. ZUP-a)}

I u ovom slučaju zakonodavac je stava da bliži odnosi službene osobe i stranke mogu predstavljati smetnju za nepristrano djelovanje u upravnom postupku. Pri tome je ovdje kao smetnja istaknut poslovni odnos koji dovodi u sumnju mogućnost pravičnog ishoda i tretmana stranke u postupku. S obzirom na postojanje drugih normi kojih je cilj izbjegavanje stvaranje i/ili održavanje takvih odnosa relativno je manja vjerojatnost potrebe za primjenom ove odredbe naspram državnih službenika ${ }^{49}$ te lokalnih službenika ${ }^{50}$ Ujedno su razlozi navedeni u spomenutim zakonskim aktima dobri primjeri odnosa na koje je usmjerena ova odredba. Posebno treba naglasiti da su odredbe iz rečenih zakonskih tekstova primjenljive i stoga što definiraju vremenske okvire koji utječu i na primjenu analizirane odredbe o fakultativnom izuzeću. ${ }^{51}$

\subsubsection{Diskriminirajuće postupanje službene osobe prema stranci (t. 3, st.3, čl. 24. ZUP-a)}

Rečeni razlog, po mom mišljenju, pogrešno je lociran u skupinu razloga za fakultativno izuzeće. Naime, diskriminativno postupanje službene osobe prema stranci teško da može ne izazvati kao svoju pravnu posljedicu izuzimanje službene osobe od djelovanja u nekom upravnom postupku. Imajući u vidu na sad već priličnu - nacionalnu i europsku - regulativu koja ima za cilj suzbiti diskriminaciju $i$ to osobito od strane službenih osoba te s obzirom na širinu zabranjenih osnova diskriminacije kao i izričitost odredbi koje definiraju krug obveznika ove regulative nije posve jasno koji su motivi vodili zakonodavca u smještanju ovog razloga među fakultativne razloge izuzeća službene osobe..$^{52}$

U tom smislu već naznaka mogućnosti diskriminatornog ponašanja službene osobe prema stranci temeljem jedne od osnova iz čl. 1, st. 1. Zakona o suzbijanju

49 V. u tom smislu čl. 32-37 Zakona o državnim službenicima, Narodne novine br. 92/05 do 138/15.

50 V. u tom smislu čl. 38-41 Zakona o službenicima i namještenicima u lokalnoj i područnoj (regionalnoj) samoupravi, Narodne novine br. 86/08 i 61/11.

51 Primjer pružaju neke odredbe čl. 41. Zakona o službenicima i namještenicima u lokalnoj i područnoj (regionalnoj) samoupravi. V. npr. odredbu al.c).

52 Uvodno o ovoj tematici na nacionalnoj razini v. Grgić, A.; Potočnjak, Ž.; Rodin, S.; Selanec, G.; Šimonović Einwalter, T.; Uzelac, A., Vodič uz Zakon o suzbijanju diskriminacije, Zagreb, 2009. Analizu primjene antidiskriminacijskog zakonodavstva v. kod Poretti, P., "Antidiskriminacijsko zakonodavstvo i sudska praksa u RH - individualna i udružna antidiskriminacijska tužba kao (ne)djelotvorna sredstva za ostvarenje pravne zaštite", u: Zbornik Pravnog fakulteta Sveučilišta u Rijeci, br. 2/2015, str. 907-944. Što se regulative na razini EU-a te Vijeća Europe tiče, u tom pogledu v. npr. Gerards, J. H., Recent case-law of the European Court of Human Rights on Non-Discrimination, zatim rad Lahuerta, S. B, Taking EU Equality Law to the Next Level: in Search of Coherence, kao i Howarda, E., Reasonable accommodation of religion and other discrimination grounds in EU law, koji radovi su bili referirani na skupu koji je pod nazivom "Current reflections on EU anti-discrimination law", a u organizaciji Europäische Rechtsakademie, održan 6.-7. VI. 2016. u Trieru (materijali sa skupa). Zanimljiv uvid na temelju analize partikularnog područja v. kod McCrea, R., "Singing from the Same Hymn Sheet?What the Differences betrween the Strasbourg and Luxembourg Courts Tell Us about Religious Freedom, Non-Discrimination and the Secular State", u: Oxford Journal of Law and Religion, br. 2, vol. 5 (2016.), str. 1-28. 
Mr. sc. Ivan Šprajc: Institut izuzeća službene osobe u Zakonu o općem upravnom postupku Zbornik radova Pravnog fakulteta u Splitu, god. 55, 2/2018., str. 469.- 496.

diskriminacije vodi prema zaključku o neodrživosti zadržavanja dotične službene osobe u tom svojstvu u upravnom postupku. ${ }^{53}$ Posebno treba naglasiti da se analizirana odredba čini dodatno insuficijentna kada se uoči njezin skroman personalni doseg (naspram pravnog dobra koje se odredbom štiti); postoje više nego dovoljni razlozi da se i diskriminirajuće postupanje prema zastupniku stranke također kvalificira kao razlog izuzeća. ${ }^{54}$ Sve izloženo učvršćuje me u stavu da je dotičnu odredbu potrebno proširiti glede njezina personalnog opsega, ali i premjestiti među razloge obligatornog izuzeća. U tom smislu plediram za takav potez zakonodavca pri prvoj sljedećoj noveli ZUP-a. Kao još jedan razlog koji vrlo vjerno ilustrira potrebu naznačene zakonske novele navodimo situaciju koja može nastati nakon utvrđenja diskriminacije na međunarodnom forumu. U ovom slučaju radi se o Europskom sudu za ljudska prava koji je u jednom slučaju konačno utvrdio diskriminaciju pred domaćim upravnim (i sudskim) tijelima. Riječ je o presudi spomenutog foruma $\mathrm{u}$ predmetu Pajić v. Hrvatska (presuda od 23. II. 2016.). ${ }^{55}$

Po sadašnjem stanju ZUP-a čak ni ova situacija ne predstavlja obligatoran razlog izuzeća bez obzira na uvjerljivost argumenata presude Europskog suda za ljudska prava odnosno stručnosti foruma koji je diskriminaciju utvrdio. Bolji dokaz potrebe za zakonskom novelom smatram da se ne može navesti. Ovo tim više jer je u slučaju Pajić Europski sud za ljudska prava izrijekom potvrdio i sljedeće: „Konačno, Sud bi još jednom naglasio kako se ovaj predmet ne odnosi na pitanje je li zahtjev podnositeljice za spajanjem obitelji trebao biti odobren u danim okolnostima slučaja. On se odnosi na pitanje jesu li podnositeljice bile diskriminirane zbog činjenice da su domaća tijela smatrala kako je takva mogućnost u svakom slučaju bila pravno nemoguća...". ${ }^{56}$ Dakle, i po odluci Europskog suda za ljudska prava o

53 Zakon o suzbijanju diskriminacije, Narodne novine br. 85/08 i 112/12; dalje: ZOSD. Čl. 1, st. 1. ZOSD-a koji nabraja zabranjene osnove diskriminacije glasi: "Ovim se Zakonom osigurava zaštita i promicanje jednakosti kao najviše vrednote ustavnog poretka Republike Hrvatske, stvaraju se pretpostavke za ostvarivanje jednakih mogućnosti i uređuje zaštita od diskriminacije na osnovi rase ili etničke pripadnosti ili boje kože, spola, jezika, vjere, političkog ili drugog uvjerenja, nacionalnog ili socijalnog podrijetla, imovnog stanja, članstva u sindikatu, obrazovanja, društvenog položaja, bračnog ili obiteljskog statusa, dobi, zdravstvenog stanja, invaliditeta, genetskog naslijeđa, rodnog identiteta, izražavanja ili spolne orijentacije." Opširnije o oblicima diskriminacije v. Selanec, G., "Oblici diskriminacije”, u: Grgić, A.; Potočnjak, Ž.; Rodin, S.; Selanec, G.; Šimonović Einwalter, T.; Uzelac, A., Vodič uz Zakon o suzbijanju diskriminacije, Zagreb, 2009., str. 30-57.

54 Valja uzeti u obzir i područje primjene ZOSD-a koje je zakonski definirano u čl. 8. ovog akta i koje obuhvaća praktički sve pravne subjekte (jer se odnosi na postupanje državnih tijela, tijela jedinica lokalne i područne (regionalne) samouprave, pravnih osoba s javnim ovlastima te na postupanje svih pravnih i fizičkih osoba) u širokom broju područja koja su, u citiranoj odredbi ZOSD-a, navedena samo egzemplarno. Opširnije o širini primjene ZOSD-a v. u Selanec, G.; Simonović Einwalter, T., "Opseg i doseg Zakona o suzbijanju diskriminacije”, u: Grgić, A.; Potočnjak, Ž.; Rodin, S.; Selanec, G.; Śrimonović Einwalter, T.; Uzelac, A., Vodič uz Zakon o suzbijanju diskriminacije, Zagreb, 2009., str. 21-27.

55 U konkretnom slučaju pritužbu pred Europskom sudom za ljudska prava podnijela je državljanka Bosne i Hercegovine zbog diskriminacije u vezi s pravom na privatni život. Podnositeljica, inače $u$ stabilnoj vezi s državljankom RH, zatražila je dozvolu boravka u RH temeljem Zakona o strancima uz poziv na institut spajanja obitelji. Kako u relevantno doba u odgovarajućim propisima nije bila predviđena mogućnost spajanja obitelji temeljem odnosa osoba istog spola, visoki je europski forum zaključio o postojanju diskriminacije temeljem spolne orijentacije i o povredi prava na privatni život.

${ }_{56}$ Par. 85. iz presude Europskog suda za ljudska prava u slučaju Pajić v. Hrvatska. 
zahtjevu postavljenom u odnosnom upravnom postupku valja ponovno odlučivati što dodatno aktualizira naš prethodno izneseni prigovor. ${ }^{57}$

\subsubsection{Drugi razlozi koji dovode u sumnju nepristranost službene osobe (t. 4, st. 3, čl. 24. ZUP-a)}

Općenito navedeni razlozi - a koji ne spadaju u niti jednu prethodno analiziranu odredbu iz st. 3, čl. 24. ZUP-a - koji dovode u sumnju nepristranost službene osobe opravdavaju pozitivnu odluku o izuzeću donesenu temeljem primjene slobodne ocjene u slučaju utvrđivanja takvih razloga. Dakle, potrebno je da postoji postupovno potvrđeno postojanje barem jednog takvog razloga. Pri tome je bitno da postupovno potvrđen razlog dosegne stupanj sumnje u nepristranost službene osobe. Sumnja u ovom slučaju nije kondicionirana posebnim stupnjem no praksa - kako upravna tako i upravnosudska - mora uzeti u obzir apsolutnu narav nepristranosti službene osobe i to kako naspram sudionika konkretnog postupka tako i same upravne stvari. Stoga bi se mogla postaviti preporuka da čak i niži stupanj vjerojatnosti u pogledu postojanja razloga koji negativno utječe na nepristranost službene osobe mora voditi odluci o izuzeću službene osobe. Drugačiji stav predstavlja nepotreban pritisak kako na službenu osobu tako i na sam postupak u kojem će se nepotrebno gomilati razlozi za žalbu te posljedično i za produženje konkretnog postupka. Zbog navedenog će već i dojam o pristranosti službene osobe, uvjeren sam, biti dovoljan da se službena osoba izuzme od postupanja i odlučivanja u postupku. Orijentacijsku vrijednost pri donošenju ovakve odluke svakako će imati i buduća upravna odnosno upravnosudska praksa.

\subsection{Primjena instituta izuzeća}

S obzirom na narav instituta izuzeća koje izravno tangira sposobnost službene osobe da odlučuje o zahtjevu za izuzećem, u postupovnoj realizaciji ovog instituta postoje određene posebnosti. One najviše dolaze do izražaja u pogledu tijela nadležnog za donošenje odluke o traženom izuzeću no s obzirom na važnost službene osobe u konkretnom postupku niti sama odluka kojom se službena osoba izuzima nije lišena svake postupovne posebnosti. U nastavku rada analiziraju se odredbe relevantne za primjenu instituta izuzeća službene osobe.

57 Kao mogući izlaz iz ovakve situacije valjalo bi na odgovarajući način primijeniti upravnosudsku praksu koja se odnosi na pravne posljedice izuzimanja službene osobe u upravnom postupku. Prema sentenci tada Upravnog suda RH: „Osoba koja je izuzeta u upravnom postupku ne može voditi ponovni postupak nakon što je sud poništio upravni akt" (USRH, br. Us-3426/02 od 26. VI. 2003.). 


\subsubsection{Inicijativa}

Inicijativa za primjenu instituta izuzeća može doći od stranaka (putem posebnog zahtjeva), ali i od strane službene osobe (ex officio). Štoviše, dužnost obavijesti nadležnog tijela o postojanju razloga za izuzeće postoji - statuirana u st. 4, čl. 24. ZUP-a - i na strani službene osobe koja vodi pojedini upravni postupak pa u tom slučaju sama službena osoba koja će u nastavku postupka biti izuzeta od postupanja daje poticaj nadležnom tijelu za primjenu instituta. Istodobno, rečena je dužnost izvor informacija za nadležno tijelo temeljem kojih se može aktivirati institut izuzeća. Spomenuta dužnost obavještavanja nadležnog tijela o postojanju razloga za izuzeće službene osobe, smatram, odnosi se na svaku grupu razloga za izuzećem - bilo da se radi o razlozima iz st. 1, odnosno iz st. 3, čl. 24. ZUP-a. Dužnost tereti svaku osobu koja sudjeluje u postupku što valja shvatiti ekstenzivno ako se kao cilj primjene izuzeća vidi osiguranje nepristranosti odlučivanja u upravnom postupku. Dakle, bez obzira na to o kojoj se postupovnoj ulozi radilo, svaki nositelj postupovne uloge u konkretnom postupku dužan je nadležnom tijelu prenijeti informacije koje mogu dovesti do utvrđivanja nekog od razloga za izuzeće službene osobe.

\subsubsection{Nadležnost}

Nadležnost za odlučivanje o izuzeću regulirana je u st. 1-3. te u st. 5, čl. 24. ZUP-a. Citirane odredbe ujedno predstavljaju naznačenu posebnost instituta izuzeća koja proizlazi iz njegove svrhe, a dotična se ogleda u potrebi osiguranja nepristranosti te eliminacije osobnih, privatnih motiva iz odlučivanja o upravnoj stvari koja je predmet konkretnog postupka. Baš zbog tako označene svrhe instituta izuzeća potrebno je da o postavljenom zahtjevu za izuzećem odlučuje druga osoba, a ne službena osoba iz konkretnog postupka. Stoga je u relevantnim dijelovima odredbi st. 1-3, čl. 24. ZUP-a određeno da o izuzeću službene osobe odlučuje čelnik tijela kojeg službena osoba čije se izuzeće traži predstavlja u konkretnom postupku. No, ako se mora odlučiti o izuzeću čelnika prvostupanjskog tijela, tada se primjenjuje pravilo iz st. 5, čl. 24. ZUP-a koje predviđa nadležnost za ovu odluku čelnika višeg, drugostupanjskog tijela. Naravno, moguće je da takvo tijelo ne postoji u kojem slučaju o izuzeću ima odlučiti tijelo koje obavlja nadzor nad tijelom za čijeg čelnika se izuzeće traži.

Iako su prikazana pravila sadržajno posve prihvatljiva, iz perspektive osiguranja svrhe instituta izuzeća njihova primjena može rezultirati znatnim problemima. Problemi se prije svega tiču detektiranja nadležnog tijela i to specijalno u situaciji supsidijarne nadležnosti iz st. 5, čl. 24. ZUP-a, a koja se odredba odnosi na odlučivanje o izuzeću čelnika prvostupanjskog tijela. Ovovrsni problemi mogu biti stvoreni ako se ima odlučiti o izuzeću čelnika prvostupanjskog tijela koje je ustrojeno kao samostalna pravna osoba sui generis. Ukoliko se još radi o karakterističnoj situaciji gdje dotična organizacija odgovara isključivo Hrvatskom saboru, tada se postavlja pitanje nadležnosti za odlučivanje o izuzeću čelnika takve organizacije. To je primjerice slučaj s Hrvatskom regulatornom agencijom za mrežne djelatnosti 
ili Agencijom za zaštitu osobnih podataka. ${ }^{58} \mathrm{U}$ takvim slučajevima potrebno je relevantnu odredbu interpretirati na način koji osigurava detekciju nadležnog tijela za odluku o izuzeću. U tom pogledu postoje dvije interpretativne opcije pa stoga u nastavku rada izlažemo obje.

Prva interpretacija završava zaključkom o nadležnosti Hrvatskog sabora da odluči o izuzeću čelne osobe navedenih (i sličnih) tijela javne vlasti. Interpretativna logika u takvom slučaju polazi od stava da norma koja uspostavlja isključivo odgovornost neke samostalne organizacije sui generis naspram Hrvatskog sabora mora biti shvaćena šire i to toliko šire da uključi u svoj sadržaj i odgovornost za zakonitost rada. Pri tome se kao ključne ističu logička te teleološka metoda tumačenja zadanog normativnog mjesta. Interpretacija, uvjeren sam, treba poći od shvaćanja da odgovornost za svoj rad nekom tijelu pojmovno obuhvaća i nadzorne ovlasti tijela kojem se za svoj rad odgovara (ovdje Hrvatski sabor). Naime, po mom shvaćanju, odgovornost za rad obuhvaća i odgovornost za zakonitost rada, a to onda neminovno uključuje i pitanje zakonitosti provedenih postupaka odnosno donesenih akata. Kao dodatak ovoj logičkoj interpretaciji treba dodati i teleološko shvaćanje svrhe rečene odredbe o odgovornosti za rad. Naime, ovlast na vođenje upravnog postupka ne bi bila potpuna ako uz nju ne bi išla i odgovornost za zakonitost takvih postupaka (odnosno zakonitost akata donesenih u istim upravnim postupcima). Onemogućavanje primjene ovako važne odredbe i instituta iz ZUP-a samo zato jer izrijekom nije navedeno ne bi trebala spriječiti primjenu interpretativne logike koja polazi za tim da se u svakom upravnom postupku mora osigurati u osnovi jednakopravan položaj stranaka. U suprotnom postoji opasnost od diskriminacije stranaka u upravnim postupcima koje vode tijela s jednakim ili bitno sličnim pravnim položajem kakve posjeduju navedene agencije. Osim toga, to bi utjecalo i na druge dijelove/institute ZUP-a pa bi pravni položaj stranaka u postupcima pred takvim tijelima javne vlasti bio neprimjereno prekaran. ${ }^{59}$ Neprihvatljivost takvog rezultata tumačenja i primjene ZUP-a smatram da dostatno opravdava prihvaćanje goreizložene interpretacije. Ako je tome tako, tada je prihvatljivo i da Hrvatski sabor svojim djelovanjem omogući zakonitost rada određene organizacije, a u slučaju izuzeća to znači da odluči o zahtjevu za izuzećem službene osobe dotične organizacije. U tom smislu može se postaviti teza da odgovornost neke organizacije prema Hrvatskom saboru posjeduje svoj komplementarni dio u dužnosti Hrvatskog sabora da svojom odlukom o izuzeću čelnika te organizacije osigura nepristranost kao sastavni dio zakonitog djelovanja organizacije u konkretnom upravnom postupku.

Druga interpretativna opcija polazi od po mom mišljenju neuvjerljivog stava o postojanju svih uvjeta za primjenu čl. 15, st. 2. ZUP-a u kojem su postavljena

58 V. čl. 7, st. 3. Zakona o elektroničkim komunikacijama, Narodne novine br. 73/08 do 71/14 odnosno čl. 28, st. 1. Zakona o zaštiti osobnih podataka Narodne novine br. 103/03 do 106/12.

59 U pogledu primjene izvanrednih pravnih lijekova iz ZUP-a v. Šprajc, I., „Korištenje izvanrednih pravnih lijekova protiv upravnih akata Državne komisije za kontrolu postupaka javne nabave“, u: Hrvatska pravna revija br. 1/2015, str. 20-31 (osobito str. 28-29). 
supsidijarna pravila o određivanju stvarne nadležnosti. ${ }^{60}$ Neuvjerljivost je posljedica stava da zakon ipak pruža dostatne osnove za stvaranje zaključka o nadležnosti za odlučivanje u konkretnim slučajevima. Međutim, u slučaju primjene čl. 15, st. 2. ZUP-a moralo bi se pristati uz stav da se na temelju zakona ne može utvrditi stvarna nadležnost u ovom slučaju pa se o nadležnosti za odlučivanje o izuzeću čelnika navedenih agencija onda ima zaključiti ili temeljem naravi upravne stvari (što ukazuje na nadležnost odgovarajućih tijela državne uprave; primjerice, Ministarstva pomorstva, prometa i infrastrukture u slučaju koji se tiče Hrvatske regulatorne agencije za mrežne djelatnosti) ${ }^{61}$ ili temeljem primjene odredbe čl. 15, st. 2. ZUP-a u kojem slučaju se dolazi do nadležnosti ,prvostupanjskog tijela državne uprave u djelokrugu kojeg su poslovi opće uprave“. Relevantne odredbe u tom pogledu nalaze se u Zakonu o sustavu državne uprave pa preostaje zaključiti da bi u ovom slučaju nadležnost za odlučivanje postojala na strani mjesno nadležnog ureda državne uprave u županiji. ${ }^{62}$ Po mom mišljenju prvonavedena interpretativna opcija superiorna je suprotstavljenoj drugoj pa sam uvjeren da je Hrvatski sabor jedina prava adresa za odlučivanje o izuzeću čelnika spomenutih agencija.

Međutim, još se problematičnijim čine pravila o nadležnosti za izuzeće koja postoje u nekim posebnim upravnim zakonima. Štoviše, radi se o takvim pravilima koja u analiziranom segmentu uzrokuju i više od osnovane sumnje o svojoj normativnoj manjkavosti što se negativno reperkusira na zaključak o osiguranju nepristranosti. Takav slučaj postoji, primjerice, u Zakonu o zaštiti tržišnog natjecanja (dalje: ZOZTN). Riječ je o čl. 56, st. 4. i 5. koje citiramo u cijelosti:

(1) Osoba ovlaštena za vođenje postupka u Agenciji, može se izuzeti od rada u predmetu ako:

1. je ta osoba ili član njezine uže obitelji imatelj više od 3 posto dionica ili udjela u poduzetniku koji je stranka u postupku,

2. je u svojstvu nezavisnog stručnjaka - eksperta dala iskaze ili pisana mišljenja o pojedinim pitanjima koji su u svezi s predmetom tog postupka,

3. se iz drugih opravdanih razloga ne može očekivati objektivno vođenje postupka i objektivno donošenja odluke u predmetu.

(2) Osobe iz stavka 1. ovoga članka, dužne su bez odgađanja pisanim putem izvijestiti Vijeće o postojanju nekog od razloga navedenih u stavku 1. ovoga članka.

(3) Zahtjev za izuzeće ovlaštene osobe iz stavka 1. ovoga članka može podnijeti i stranka u postupku koji se vodi u Agenciji. Zahtjev se podnosi u pisanom obliku.

60 Čl. 15, st. 2. ZUP-a glasi: “Ako se stvarna nadležnost ne može utvrditi na temelju zakona, niti je to moguće utvrditi po naravi upravne stvari, stvarno je nadležno prvostupanjsko tijelo državne uprave u djelokrugu kojeg su poslovi opće uprave."

${ }^{61}$ Arg. ex čl. 15, st. 2. Zakona o ustrojstvu i djelokrugu ministarstava i drugih središnjih tijela državne uprave, Narodne novine br. 150/11 do 148/13 za Ministarstvo pomorstva, prometa i infrastrukture.

${ }_{62}$ Čl. 3, st. 2. Zakona o sustavu državne uprave, Narodne novine br. 150/11 i 12/13 glasi: "Ministarstva, državni uredi i državne upravne organizacije središnja su tijela državne uprave, a uredi državne uprave u županijama su prvostupanjska tijela državne uprave." 
Mr. sc. Ivan Šprajc: Institut izuzeća službene osobe u Zakonu o općem upravnom postupku Zbornik radova Pravnog fakulteta u Splitu, god. 55, 2/2018., str. 469.- 496.

(4) Odredbe ovoga članka na odgovarajući se način odnose i na članove Vijeća.

(5) O zahtjevima za izuzeće iz članka 55. i 56. ovoga Zakona odlučuje Vijeće.

Navedena specijalna norma već prima faciae otkriva dvojbeni normativni stav zakonodavca. Međutim, niti jednu dvojbu ne dopušta usporedba citiranog mjesta iz ZOZTN-a s čl. 3, st. 1. u vezi s čl. 24. ZUP-a. Navedene odredbe ZUP-a ukazuju da je čl. 24. ZUP-a u statusu apsolutno i općevažeće odredbe koja je uz to sastavni dio temeljnih odredbi ZUP-a. ${ }^{63}$ Temeljne odredbe ZUP-a, među inima, predstavljaju onu granicu koju posebni upravni postupci ne smiju prekoračiti sadržajem svojih posebnih upravnopostupovnih normi ${ }^{64}$ Kako, prema čl. 24. ZUP-a, nije dopušteno institut izuzeća u posebnim upravnim postupcima regulirati na način koji odstupa od citirane temeljne odredbe ZUP-a, jednostavna usporedba čl. 56, st. 4-5 ZOZTN-a i čl. 24, st. 5. ZUP-a ukazuje na transgresivni pa stoga i pravno neprihvatljivi sadržaj posebne postupovne norme. Dodamo li tome i spoznaju da ZOZTN nije organski zakon, a ZUP jest, ne postoje nikakve logičke prepreke zaključiti da su analizirane odredbe ZOZTN-a u neskladu s načelom ustavnosti i zakonitosti. ${ }^{65} \mathrm{U}$ sadržajnom smislu, također, nije jednostavno obraniti stav o tome da o izuzeću kolegijalnog tijela odlučuju članovi tog istog tijela. Riječ je o neprihvatljivom konfudiranju i dodjeljivanju postupovnopravnih ovlasti koje inače pripadaju čelniku tijela. Netom izneseni primjer ukazuje na potrebu pažljivije i temeljitije analize važećeg zakonodavstva, ali ništa manje ni akata koji ulaze u zakonodavni postupak. Ipak, u većini zakona koji uređuju funkcioniranje samostalnih pravnih osoba postoji jasna naznaka tijela koje vrši nadzor nad takvim osobama pa ne nastaju problemi vezani za eventualno odlučivanje o izuzeću čelnika takvih osoba. ${ }^{66}$

\subsubsection{Zaključak o izuzeću te o mogućnosti pravne zaštite}

Sukladno izričitoj odredbi st. 5, čl. 24. ZUP-a, o izuzeću se odlučuje zaključkom. Izbor zaključka kao pravne forme akta u ovom slučaju pokazuje se opravdanim; riječ je o postupovnom pitanju pa nije potrebno odlučivati rješenjem. To proizlazi iz čl. 77, st. 1. ZUP-a koji uređuje polje primjene zaključka kao pravnog akta. Drugo je pak pitanje oblika zaključka u konkretnoj situaciji. Naime, kako je zaključak koncipiran kao usmena pravna forma, pismenost zaključka određena je kao izuzetak od pravila. Prema st. 4. čl. 77. ZUP-a pismeni zaključak donosi se samo u dva slučaja; prvo, kad to zatraži stranka i drugo, kad je to nužno radi pravilnog vođenja postupka.

63 Više o tome v. kod Šprajc, I., Uvjeti propisivanja..., str. 60.

64 V. iznimke od toga kod Šprajc, I., op. cit, str. 61.

65 V. Šprajc, I., op. cit, str. 62-63.

66 V. u potvrdu primjere koji pružaju Zakon o Agenciji za regulaciju tržišta željezničkih usluga, Narodne novine br. 79/07 do 61/11, Zakon o Agenciji za strukovno obrazovanje i obrazovanje odraslih, Narodne novine br. 24/10, Zakon o sigurnosti i interoperabilnosti željezničkog sustava, Narodne novine br. 82/13 do 110/115 u vezi s Agencijom za sigurnost željezničkog prometa te Zakon o osiguravanju kvalitete u znanosti i visokom obrazovanju, Narodne nvoine br. 45/09 u vezi s Agencijom za znanost visoko obrazovanje. 
Obje situacije moguće su i pri odlučivanju o izuzeću službene osobe. Prva ovisi o traženju stranke koja je tražila izuzeće (iz čega izlazi da, ukoliko stranka ne zatraži donošenje pisanog zaključka, zaključak će joj biti priopćen usmeno), a druga ovisno o ocjeni tijela nadležnog da odluči o izuzeću. U literaturi se mogu naći stavovi prema kojima postupak o izuzeću pokrenut ex offo koji nije doveo do izuzeća znači da se „ne mora donijeti poseban zaključak. " ${ }^{67}$ Smatramo da se citirani autor zapravo zalaže za donošenje usmenog zaključka, a ne za nedonošenje odluke uopće. Naime, o izuzeću se, bez obzira na inicijativu, mora odlučiti, a pitanje forme ovisi ili o dispoziciji stranaka (kada stranke traže izuzeće službene osobe) ili o ocjeni službene osobe o nužnosti donošenja pisanog zaključka zbog pravilnog vođenja postupka. Ne vidimo prepreku da nadležno tijelo donese pisani zaključak o izuzeću i kada je postupak pokrenut ex offo te da se o tom zaključku obavijesti i stranka. Naime, to može imati blagotvorni utjecaj i na moguće stranačko traženje izuzeća (jer se stranka obavještava o stavu službene osobe o (ne)postojanju konkretnog razloga za izuzećem), a time se ujedno realizira i načelo učinkovitosti i ekonomičnosti što utječe na pravilnost vođenja upravnog postupka. Nadalje, jednako je tako zamisliva situacija u kojoj se stranka nije odlučila tražiti donošenje pisanog zaključka pri čemu ipak smatramo da bi u takvom slučaju službena osoba morala upozoriti stranku na tu njezinu dispoziciju, a poradi kasnijeg korištenja pravne zaštite protiv odluke o izuzeću što ujedno može značiti i realizaciju načela pomoći stranci.

Posebnost zaključka o izuzeću ogleda se u situaciji kada se pozitivno odluči o izuzeću. Tada je, očito iz razloga realizacije načela učinkovitosti i ekonomičnosti, sastavni dio zaključka i određenje nove službene osobe koja će voditi postupak i rješavati o upravnoj stvari. I u ovom slučaju vidimo potrebu donošenja pisanog zaključka, a poradi pravilnog vođenja postupka odnosno postizanja većeg stupnja pravne sigurnosti. Razlog tome je primarno preciznost u određivanju kako momenta od kojeg vođenje postupka preuzima nova službena osoba, tako i jasnog određenja nove službene osobe. Po naravi stvari, odluka o izuzeću i odluka o određivanju nove službene osobe moraju se nalaziti u dispozitivu pisanog zaključka. Obje ove okolnosti izuzetno su bitne i iz perspektive stranke kojoj bi se, po mom mišljenju, ovakav zaključak morao dostaviti bez obzira na to je li ona inicirala izuzeće. Tako se na najpotpuniji način realizira još jedno važno načelo upravnog postupanja, a to je načelo pristupa podacima i zaštite podataka.

Pravna zaštita protiv zaključka o izuzeću određena je čl. 77, st. 5. ZUP-a. Nastavno tome, svim zainteresiranim osobama otvoren je put pravne zaštite koji vodi preko rješenja donesenog u upravnoj stvari u kojoj je odlučeno o izuzeću. Dakle, iako zaključak nije - i ne može biti - izravni objekt pravozaštitnog sredstva (žalbe), njegovo osporavanje nije potpuno isključeno već je omogućeno neizravno, putem žalbe protiv rješenja u istoj upravnoj stvari. U takvoj situaciji pristajemo uz stav jednog autora koji navodi da se kao najizgledniji žalbeni razlog u takvom slučaju ističe bitna povreda postupka. ${ }^{68}$ Propuštanje žalbe protiv rješenja nije iz

67 Tako Turčić, Z., op. cit, str. 74.

68 Tako i Turčić, Z., op. cit, str. 74. 
perspektive zainteresirane osobe nenadoknadiva pogreška. Naime, nakon nastupa nemogućnosti korištenja žalbe, zainteresiranim osobama otvara se mogućnost predlaganja obnove postupka i to pozivom na odredbu čl. 123, st. 1, t. 3. ZUP-a. Prema citiranoj odredbi, kao razlog obnove upravnog postupka navodi se da je rješenje donijela „osoba koja je morala biti izuzeta“. Dikcija ovog zakonskog mjesta ukazuje, prima vista, da se mogućnost predlaganja obnove postupka odnosi isključivo na razloge obligatornog izuzeća; dakle, na razloge iz čl. 24, st. 1. i 2. ZUP-a. ${ }^{69}$ Ipak, poznavajući institut „redukcije diskrecije“ (koji dolazi iz njemačkog upravnog prava), moglo bi se zamisliti i situacije koje se tiču razloga za fakultativno izuzeće (iz st. 3. čl. 24. ZUP-a), a koje bi se morale smatrati više no dovoljnim za pokretanje obnove postupka. Spomenuti institut, koji svoju relativno čestu primjenu nalazi u njemačkom upravnom pravu, zasniva se na shvaćanju da ponekad sloboda izbora pri vršenju slobodne (diskrecijske) ocjene može biti tako sužena da nadležno tijelo može odabrati samo jednu od više opcija. ${ }^{70}$ Razlog takvog „sužavanja“ slobodne ocjene najčešće se opravdava okolnostima konkretnog slučaja te potrebom odvraćanja opasnosti po neko vrlo bitno pravno dobro. Po mom mišljenju jednakost je upravo takvo pravno dobro koje opravdava institut ,redukcije diskrecije“. To bi svakako utjecalo i na primjenu instituta obnove postupka temeljem jednog od razloga fakultativnog izuzeća iz st. 3, čl. 24. ZUP-a. Najuvjerljivija situacija i razlog koji konkuriraju za primjenu obnove postupka iz st. 3. čl. 24. ZUP-a po mom mišljenju su slučajevi u kojima je diskriminacija sudski ustanovljena temeljem postupka vođenog sukladno Zakonu o suzbijanju diskriminacije. Naime, već po samom području primjene ovog zakonskog akta, diskriminacija se osobito ima suzbijati u postupanju tijela u području pravosuđa i uprave..$^{71}$ Dakle, diskriminacija stranke od strane službene osobe ustanovljena pravomoćnom sudskom odlukom, držim, mora biti više nego dovoljan razlog za obnovu prethodno okončanog upravnog postupka, a pozivom na čl. 123, st. 1, čl. 3. ZUP-a. U takvom bi slučaju, uvjeren sam, diskrecija nadležnog tijela i službene osobe iz čl. 23, st. 3, t. 3. ZUP-a praktički nestala te bi obnova postupka bila jedino prihvatljivo pravno sredstvo za restauriranje narušenog povjerenja u nepristranost službene osobe.

No čak i da diskriminacija nije prethodno dokazana u sudskom postupku vođenom po ZSD-u već ustanovljavanje vjerojatnosti diskriminiranja u istom postupku govori u prilog ozbiljnog razmatranja tako argumentiranog zahtjeva za izuzećem u paralelno vođenom upravnom postupku. Naime, posebna postupovna pravila iz ZSD-a - čl. 19-20. ZSD-a - razinu dokazivanja diskriminacije pomiču u smjeru dokazivanja nepostojanja diskriminacije i to nakon što se diskriminacija

69 Tako i Turčić, Z., op. cit, str. 74.

70 V. opširnije o spomenutom institute Suckow, H.; Weidemann, H., Allgemeines Verwaltungsrecht und Verwaltungsrechtsschutz, 16. izdanje, Stuttgart, 2014., str. 162-163 te Ipsen, J., Allgemeines Verwaltungsrecht, 4. izdanje, Köln-Berlin-München, 2005., str. 159-160, uz navođenje sudske prakse njemačkog saveznog Upravnog suda.

71 V. čl. 8. ZSD-a. 
učini prima faciae vjerojatnom. ${ }^{72} \mathrm{U}$ slučaju paralelno vođenih postupaka (sudskog o diskriminaciji stranke od službene osobe u upravnom postupku i upravnog o nekoj upravnoj stvari) kao i u slučaju da sudski postupak još nije pokrenut, pitanje diskriminacije u upravnom postupku postaje prethodno pitanje. ${ }^{73}$ Stoga bi tako određenu postupovnu situaciju u upravnom postupku bilo sukladno ZUP-u moguće razriješiti na dva načina; a) prekinuti upravni postupak dok se ne odluči o postojanju diskriminacije pred nadležnim sudom (uz mogućnost formalnog poticanja stranke na pokretanje takvog sudskog postupka sukladno čl. 56, st. 3. ZUP-a) ${ }^{74}$ ili b) usvojiti zahtjev za izuzećem dotične službene osobe i omogućiti nastavak upravnog postupka. Razlozi ekonomičnosti te učinkovitosti pretežu u korist druge postupovne opcije jer u suprotnom upravni postupak mora čekati pravomoćnost odluke iz sudskog postupka.

\section{ZAKLJUČNA RAZMATRANJA}

Analiza instituta izuzeća iz ZUP-a pokazala je sljedeće:

- Institut izuzeća prilično je zanemaren institut, mjereno prema dosadašnjim analizama i obradama ovog instituta. Ne postoje razlozi koji bi to mogli opravdati, uzme li se u obzir njegova važnost za realizaciju ključnih normi ZUP-a, još konkretnije samih načela ZUP-a. Bez ovog instituta načelima zakonitosti, utvrđivanja materijalne istine, samostalnosti i slobodne ocjene dokaza te razmjernosti u zaštiti prava stranaka i javnog interesa, naprosto bi nedostajao neizostavni dio njihove normativne konstrukcije što bi porazno djelovalo na njihovu primjenu. Nadalje, institut izuzeća povezan je zbog svog učinka i s drugim pravnim institutima - izvan područja upravnog prava pa i prava općenito - a zapažen utjecaj vrši i u svakodnevnom političkom životu i praksi. Institut sukoba interesa dobar je primjer za izrečeno te dodatna ilustracija važnosti instituta izuzeća kao sastavnog dijela mehanizma rješavanja sukoba interesa odnosno prevencije korupcije unutar političke zajednice.

- Osim toga, važnost instituta izuzeća dodatno se potvrđuje unutar EUprava za što smo kao primjer takve tvrdnje istaknuli i uvodno prikazali mjesto ovog instituta unutar prava na dobru administraciju kao dijela Povelje o temeljnim pravima EU-a (čl. 41.). Kada se tome doda i status

72 V. podrobnije Uzelac, A., "Postupak pred sudom”, u: Grgić, A.; Potočnjak, Ž.; Rodin, S.; Selanec, G.; Šimonović Einwalter, T.; Uzelac, A., Vodič uz Zakon o suzbijanju diskriminacije, Zagreb, 2009., str. 101-102, kao i Rodin, S., "Dokazivanje diskriminacije i teret dokazivanja u pravu Europske unije", u istom djelu, str. 109-112.

73 Oko određenja prethodnog pitanja u upravnom postupku u potpunosti se slažemo s Đerđom, D., Opći upravni postupak u Republici Hrvatskoj, Zagreb, 2010., str. 145. Glede postupaka koji se odnose na pitanje postojanja diskriminacije u potvrdu takvog stava Uzelac, A., op. cit, str. 95-96.

74 V. naravno iznimke od ove opcije iz čl. 55, st. 2. ZUP-a. 
Mr. sc. Ivan Šprajc: Institut izuzeća službene osobe u Zakonu o općem upravnom postupku Zbornik radova Pravnog fakulteta u Splitu, god. 55, 2/2018., str. 469.- 496.

dotičnog prava u praksi Europskog suda pravde, jasno je da je teza o važnosti instituta izuzeća potvrđena. Sve to, mišljenja sam, predstavlja poticaj na istraživanje kako prava na dobru upravu tako i instituta izuzeća.

- Unutar ZUP-a iz 2009. g. institut izuzeća također je normativno redizajniran. Institut nije drastično promijenjen, a rezultat promjena je višeznačan; s jedne strane, institut je usavršen, a s druge strane, mogu se zamijetiti i određeni nedostaci kojih prije 2009. g. nije bilo. Dakle, promjena nije rezultirala samo poboljšanjima što konačnu ocjenu normativnog redizajna smješta u zonu prosječnosti. Netom izrečena konstatacija, smatram, obvezuje stručnu javnost, ali i zakonodavca na dodatno usavršavanje instituta.

- Temeljni nedostatak relevantnih odredbi instituta izuzeća posljedica je promjena u zakonodavstvu koje su se dogodile u području obiteljskog prava. Naime, zakonodavne promjene koje se odnose na izvanbračnu zajednicu kao i na životno partnerstvo osoba istog spola dovele su do normativne zastarjelosti odredbi ZUP-a o izuzeću. Stoviše, s obzirom na nedostatke relevantnih normi, može se ustvrditi da su bračni drugovi sada diskriminirani naspram izvanbračnih drugova odnosno osoba istog spola koji su registrirali životno partnerstvo. Takvo normativno stanje vidim kao više nego dovoljno snažan poticaj za koncipiranje pa onda i realizaciju novele ZUP-a. U suprotnom, može doći do slučajeva diskriminacije koji zbog sve razvijenije svijesti građana o mogućnostima pravne zaštite u takvim slučajevima teško da će ostati neregistrirani u odgovarajućim pravnim postupcima. Slučajevi poput nedavno okončanih pred Europskim sudom za ljudska prava (Pajić v. Hrvatska odnosno Guberina v. Hrvatska) to zorno potvrđuju. ${ }^{75} \mathrm{U}$ rečenom kontekstu, posebnu pozornost treba obratiti na pozicioniranje diskriminatornog ponašanja službene osobe kao razloga fakultativnog izuzeća. Smatram da postoje više nego dostatni razlozi da se diskriminacija stranke od strane službene osobe uvrsti na listu razloga za obligatorno izuzeće. Ključni razlog tome jest zasigurno pravno neupitni i supremativni status jednakosti pa onda i zaštite od diskriminacije što u sadašnjem tekstu ZUP-a ne dolazi dovoljno do izražaja.

- Niti u području normi koje se odnose na primjenu instituta izuzeća ne možemo zaključiti da promjene nisu potrebne. Osobito se ovakav zaključak potvrđuje kada se norma ZUP-a o izuzeću pokuša primijeniti na čelnike nekih samostalnih pravnih osoba. Na primjeru Agencije

75 U odnosu na slučaj Guberina v. Hrvatska (presuda od 22. III. 2016.) potrebno je imati na umu da presuda Europskog suda za ljudska prava još nije konačna jer je RH zatražila ispitivanje presude pred Velikim vijećem. U prvostupanjskoj presudi jednoglasno je zaključeno da je RH diskriminatorno povrijedila pravo na mirno uživanje vlasništva podnositelja. Podnositelj je zatražio izuzeće od poreza na promet nekretnina koju nekretninu je nabavio prvenstveno radi omogućavanja lakšeg pristupa svojoj obitelji te posebno svom trećem djetetu koje pati od višestrukih tjelesnih i duševnih smetnji. Ovakav zahtjev podnositelja nadležna upravna tijela odbila su jednako kao i nadležne sudske instance te Ustavni sud RH. 
za zaštitu osobnih podataka odnosno Hrvatske regulatorne agencije za mrežne djelatnosti ustanovili smo da postoji pravna neizvjesnost glede nadležnosti za odlučivanje o izuzeću čelnika takvih pravnih osoba. Posljedica je to nepostojanja posebne norme koja bi uredila ovo pitanje, ali i očitih nedostataka norme čl. 24. ZUP-a koja nije uzela u obzir da ZUP primjenjuju i specifične pravne osobe. No čak i tamo gdje postoji posebna norma koja regulira pitanje izuzeća čelnika takvih tijela, problemi nisu manji. Na primjeru DKOM-a i Agencije za zaštitu tržišnog natjecanja uvidjeli smo da posebne norme mogu neprihvatljivo aberirati od ZUP-a kao organskog zakona pri čemu valja upozoriti i na okolnost da odredba o izuzeću u ZUP-u spada u temeljne odredbe od kojih odstupanje naprosto nije dopušteno. Niti u sadržajnom pogledu posebne odredbe o izuzeću ne mogu izdržati test normativne prihvatljivosti što sve skupa usmjerava zaključke u smjeru žurne zakonodavne intervencije.

- Zaključno može se ustvrditi da se institut izuzeća mora nastaviti usavršavati te pratiti promjene u našem zakonodavstvu, a posebnu pozornost valja obratiti na posebne upravne zakone koji reguliraju ovaj institut. Njegova neizostavna i nužna prisutnost u ZUP-u razlog je tome jednako kao što njegova postupovna vrijednost nadilazi puku instrumentalnu ulogu. Nadam se da će ovaj rad biti dovoljno snažan poticaj u rečenom smjeru.

\section{LITERATURA:}

1. Androjna, V., Upravni postopek in upravni spor, Ljubljana, 1992.,

2. Babac, B., Upravno pravo (Odabrana poglavlja iz teorije i praxisa), Osijek, 2004.,

3. Đerđa, D., Opći upravni postupak u Republici Hrvatskoj, Zagreb, 2010.,

4. Gerards, J. H., Recent case-law of the European Court of Human Rights on NonDiscrimination, referat na skupu "Current reflection on EU anti-discrimination law" - Trier, 6.-7. VI. 2016.,

5. Grgić, A.; Potočnjak, Ž.; Rodin, S.; Selanec, G.; Šimonović Einwalter, T.; Uzelac, A., Vodič uz Zakon o suzbijanju diskriminacije, Zagreb, 2009.,

6. Gunter, F. N, „Corruption“, u: Encyclopedia of social problems (editor: Parrillo, V.N.), Sage, 2008., I. tom, str. 172-175,

7. Howard, E., Reasonable accommodation of religion and other discrimination grounds in EU law, referat na skupu "Current reflection on EU anti-discrimination law" - Trier, 6.-7. VI. 2016.,

8. Ipsen, J., Allgemeines Verwaltungsrecht, 4. izdanje, Köln-Berlin-München, 2005.,

9. Krijan, P., Komentar Zakona o općem upravnom postupku, 3. dopunjeno izdanje, Zagreb, 2006.,

10. Kristjánsdóttir, M. V., "Good administration as a fundamental right", Icelandic Review of Politics \& Administration, vol. 9, no. 1, 2013., str. 237-255, 
Mr. sc. Ivan Šprajc: Institut izuzeća službene osobe u Zakonu o općem upravnom postupku Zbornik radova Pravnog fakulteta u Splitu, god. 55, 2/2018., str. 469.- 496.

11. Kušan, L., Sukob interesa, Zagreb-Split, 2003.,

12. Lahuerta, S. B., Taking EU Equality Law to the Next Level: in Search of Coherence, referat na skupu "Current reflection on EU anti-discrimination law" - Trier, 6.-7. VI. 2016.,

13. McCrea, R., "Singing from the Same Hymn Sheet?What the Deifferences betrween the Strasbourg and Luxembourg Courts Tell Us about Religious Freedom, Non-Discrimination and the Secular State", u: Oxford Journal of Law and Religion, br. 2, vol. 5, 2016., str. 1-28,

14. Poretti, P., "Antidiskriminacijsko zakonodavstvo i sudska praksa u RH - individualna i udružna antidiskriminacijska tužba kao (ne)djelotvorna sredstva za ostvarenje pravne zaštite", u: Zbornik Pravnog fakulteta Sveučilišta u Rijeci, vol. 36, br. 2, 2015., str. 907-944,

15. Pünder, H., "Verwaltungsverfahren", u: H-V. Erichsen - D. Ehlers (Hrsg.), Allgemeines Verwaltungsrecht, 14. izdanje, Berlin-New York, 2010.,

16. Rodin, S., "Dokazivanje diskriminacije i teret dokazivanja u pravu Europske unije", Grgić, A.; Potočnjak, Ž.; Rodin, S.; Selanec, G.; Šimonović Einwalter, T.; Uzelac, A., Vodič uz Zakon o suzbijanju diskriminacije, Zagreb, 2009., str. 107-113,

17. Röhl, K. F.; Röhl, H. C., Allgemeine Rechtslehre - ein Lehrbuch, 3. izdanje, KölnMünchen, 2008.,

18. Selanec, G., "Oblici diskriminacije”, Grgić, A.; Potočnjak, Ž. ;Rodin, S.; Selanec, G.; Šimonović Einwalter, T.; Uzelac, A., Vodič uz Zakon o suzbijanju diskriminacije, Zagreb, 2009., str. 29-46,

19. Selanec, G.; Šimonović Einwalter, T., "Opseg i doseg Zakona o suzbijanju diskriminacije”, Grgić, A.; Potočnjak, Ž.; Rodin, S.; Selanec, G.; Šimonović Einwalter, T.; Uzelac, A., Vodič uz Zakon o suzbijanju diskriminacije, Zagreb, 2009., str. 21-29,

20. Suckow, H.; Weidemann, H., Allgemeines Verwaltungsrecht und Verwaltungsrechtsschutz, 16. izdanje, Stuttgart, 2014.,

21. Šprajc, I., "Mežnarić v. Hrvatska (Predmet br. 71615/01, Presuda Prvog vijeća Europskog suda za ljudska prava od 15. srpnja 2005.)”, u: Odvjetnik, br. 7-8/05, str. 48-50,

22. Šprajc, I., "Uvjeti propisivanja posebnog upravnog postupka: usporedba novog i starog ZUP-a", Hrvatska pravna revija, vol. 11, br. 1, 2011., str. 58-66,

23. Šprajc, I., ,Korištenje izvanrednih pravnih lijekova protiv upravnih akata Državne komisije za kontrolu postupaka javne nabave“, Hrvatska pravna revija, vol. 15, br. 1, 2015. str. 20-31,

24. Turčić, Z., Komentar Zakona o općem upravnom postupku, treće, dopunjeno izdanje, Zagreb, 2012.,

25. Uzelac, A., “Postupak pred sudom”, Grgić, A.; Potočnjak, Ž.; Rodin, S.; Selanec, G.; Šimonović Einwalter, T.; Uzelac, A., Vodič uz Zakon o suzbijanju diskriminacije, Zagreb, 2009., str. 93-107,

26. Vrban, V., Država i pravo, Zagreb, 2003.,

27. Wielinger, G., Einführung in das österreichische Verwaltungsverfahrenrcht und das Recht der österreichischen Verwaltnugsgerichtsbarkeit, Graz, 2014. 


\section{POPIS PROPISA, AKATA I SUDSKIH ODLUKA}

1. Zakon o općem upravnom postupku, Narodne novine br. 47/09,

2. Konvencija za zaštitu ljudskih prava i temeljnih sloboda, Narodne novine međunarodni ugovori br. 18/97, 6/99, 14/02, 13/03, 9/05, 1/06, 2/10,

3. Povelja o temeljnim pravima Europske Unije (OJ C 326),

4. Lisabonski ugovor (Ugovor iz Lisabona kojim se mijenja Ugovor o Europskoj Uniji i Ugovor o osnivanju Europske zajednice; OJ C 306),

5. Zakon o državnim službenicima, Narodne novine br. 92/05 do 01/15,

6. Zakon o službenicima i namještenicima u lokalnoj i područnoj (regionalnoj) samoupravi, Narodne novine br. 86/08 i 61/11,

7. Zakon o udrugama, Narodne novine br. 74/14,

8. Zakon o odvjetništvu, Narodne novine br. 9/94 do 18/11,

9. Obiteljski zakon, Narodne novine br. 103/15,

10. Zakon o životnom partnerstvu osoba istog spola, Narodne novine br. 92/14,

11. Zakon o suzbijanju diskriminacije, Narodne novine br. 85/08 i 112/12,

12. Zakon o elektroničkim komunikacijama, Narodne novine br. 73/08 do 71/14,

13. Zakon o zaštiti osobnih podataka, Narodne novine br. 103/03 do 106/12,

14. Zakon o ustrojstvu i djelokrugu ministarstava i drugih središnjih tijela državne uprave, Narodne novine br. 150/11 do 148/13,

15. Zakon o zaštiti tržišnog natjecanja, Narodne novine br. 79/09 i 80/13,

16. Zakon o Agenciji za regulaciju tržišta željezničkih usluga, Narodne novine br. 79/07 do $61 / 11$,

17. Zakon o Agenciji za strukovno obrazovanje i obrazovanje odraslih, Narodne novine br. $24 / 10$,

18. Zakon o sigurnosti i interoperabilnosti željezničkog sustava, Narodne novine br. $82 / 13$ do $110 / 15$,

19. Zakon o osiguravanju kvalitete u znanosti i visokom obrazovanju, Narodne novine br. 45/09,

20. Zakon o općem upravnom postupku, Narodne novine br. 53/91 i 103/96.

21. Europski sud za ljudska prava:

- Pajić protiv Hrvatske (presuda od 23. II. 2016. - pritužba br. 68453/13),

- Guberina protiv Hrvatske (presuda od 22. III. 2016. - pritužba br. 23682/13),

- Mežnarić protiv Hrvatske (presuda od 15. VII. 2005. - pritužba br. 71615/01),

22. Europski sud pravde:

- C-604/12 (H.N. v. Ministarstvo pravde, jednakosti i reforme prava; ECLI:EU:C:2014:302),

- C-439/11 P (Ziegler v. Europska komisija; ECLI:CU:C:2013:513), 
Mr. sc. Ivan Šprajc: Institut izuzeća službene osobe u Zakonu o općem upravnom postupku Zbornik radova Pravnog fakulteta u Splitu, god. 55, 2/2018., str. 469.- 496.

\section{Upravni sud RH (sada Visoki upravni sud $R H$ ):}

- Presuda br. Us-307/85 od 22. V. 1985.,

- Presuda br. Us-3426/02 od 26. VI. 2003.

\section{MREŽNI IZVORI}

1. I. Cuculoska, The Right to Good Administration to EU: Definition, Scope and Content, URL=http://law-review.mk/pdf/09/Irena\%20Cuculoska.pdf. Pristupljeno 23. svibnja 2016.

2. J. Mendes, Good Administration in EU Law and the European Code of Good Administrative Behaviour, European University Institute, Florence, Department of Law, EUI Working paper LAW, 2009/09, URL=http://cadmus.eui.eu/bitstream/handle/1814/12101/ LAW_2009_09.pdf;jsessionid=20A513526AB2A2FC7FBEDE9CFD80A9D2?sequen ce $=3$. Pristupljeno 30. svibnja 2016.,

3. P. Váczi, The institution of good administration in the Council of Europe, URL=https:// www.law.muni.cz/sborniky/cofola2008/files/pdf/sprava/vaczi_peter.pdf Pristupljeno 1. lipnja 2016.,

4. A. Bačić, Sukob interesa i pitanje odgovornosti u ustavnoj demokraciji, u: Rad Hrvatske akademije znanosti i umjetnosti: Razred za društvene znanosti, br. 512=49(2012),URL=http:// hrcak.srce.hr/index.php?show=clanak\&id_clanak_jezik=123762. Pristupljeno 16. svibnja 2016.,

5. T. Lankester, Conflict of Interest: A Historical and Comparative Perspective, $\mathrm{URL}=\mathrm{http}: / / \mathrm{www}$.oecd.org/site/adboecdanti-corruptioninitiative/39368062.pdf. Pristupljeno 6. svibnja 2016.

6. Ustav RH, URL=http://www.usud.hr/sites/default/files/dokumenti/Redakcijski_ prociscen_tekst_Ustava_Republike_Hrvatske_Ustavni_sud_Republike_Hrvatske_15. sijecnja_2014_.pdf. Pristupljeno 1. lipnja 2016.

\section{THE CONCEPT OF EXEMPTION OF AN OFFICIAL PERSON IN THE GENERAL ADMINISTRATIVE PROCEDURE ACT}

In this paper the author covers an important and interesting, even somewhat neglected, concept of exemption of an official person. During the analysis of the concept of exemption, author points out its obsolescence, as well as dubious solutions in provisions of special administrative legislation. Finally, the author asks for the continuation of work on the improvement of the concept, as well as for necessary legislative improvements of appropriate provisions of General Administrative Procedure Act.

Key words: exemption, official person, administrative procedure, General Administrative Procedure Act 